Florida International University FIU Digital Commons

$11-9-2012$

\title{
Spatiotemporal Variation in Abundance and Social Structure of Bottlenose Dolphins in the Florida Coastal Everglades
}

Robin E. Sarabia

Florida International University, robin.sarabia@gmail.com

DOI: $10.25148 /$ etd.FI12113006

Follow this and additional works at: https://digitalcommons.fiu.edu/etd

\section{Recommended Citation}

Sarabia, Robin E., "Spatiotemporal Variation in Abundance and Social Structure of Bottlenose Dolphins in the Florida Coastal Everglades" (2012). FIU Electronic Theses and Dissertations. 754.

https://digitalcommons.fiu.edu/etd/754 


\title{
FLORIDA INTERNATIONAL UNIVERSITY \\ Miami, Florida
}

\section{SPATIOTEMPORAL VARIATION IN ABUNDANCE AND SOCIAL STRUCTURE OF BOTTLENOSE DOLPHINS IN THE FLORIDA COASTAL EVERGLADES}

\author{
A thesis submitted in partial fulfillment of the \\ requirements for the degree of \\ MASTER OF SCIENCE \\ in \\ BIOLOGY \\ by
}

Robin Elizabeth Sarabia

2012 
To: Dean Kenneth G. Furton

College of Arts and Sciences

This thesis, written by Robin Elizabeth Sarabia, and entitled Spatiotemporal Variation in Abundance and Social Structure of Bottlenose Dolphins in the Florida Coastal

Everglades, having been approved in respect to style and intellectual content, is referred to you for judgment.

We have read this thesis and recommend that it be approved.

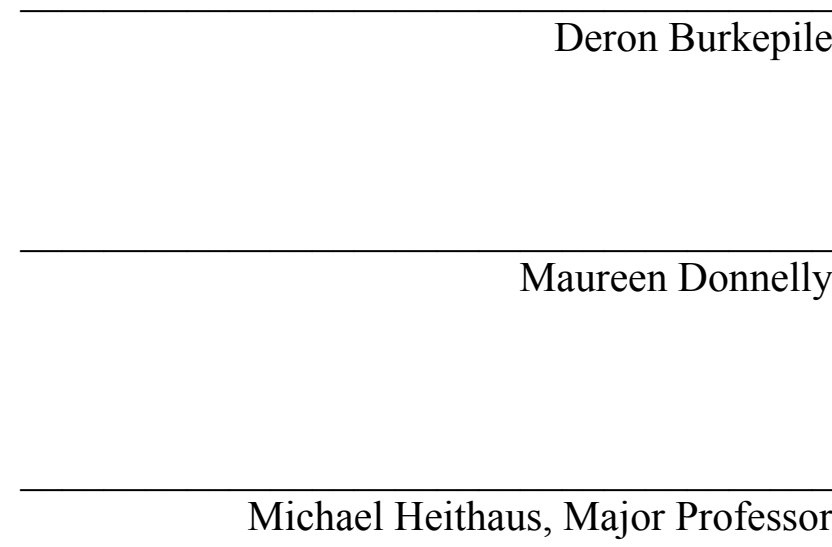

Date of Defense: November 9, 2012

The thesis of Robin Elizabeth Sarabia is approved.

Dean Kenneth G. Furton

College of Arts and Sciences

Dean Lakshmi N. Reddi

University Graduate School

Florida International University, 2012 


\section{DEDICATION}

This manuscript is dedicated to Carol Sarabia. 


\section{ACKNOWLEDGMENTS}

This manuscript only exists because of the invaluable assistance of my Major Professor, Dr. Michael Heithaus, and my committee members, Dr. Maureen Donnelly and Dr.

Deron Burkepile. This manuscript also owes its existence to the ongoing help and support of Dr. Jennifer Lewis as well as the many contributions of my peers and labmates, Laura Bhatti and Robert Nowicki in particular. Fieldwork would have not been completed without the help of Adam Rosenblatt, Phil Matich and Kirk Gastrich.

Generous financial support was provided by the Florida Coastal Everglades Long Term Ecological Research Program and the Florida International University Presidential Fellowship. 


\begin{abstract}
OF THE THESIS
SPATIOTEMPORAL VARIATION IN ABUNDANCE AND SOCIAL STRUCTURE

OF BOTTLENOSE DOLPHINS IN THE FLORIDA COASTAL EVERGLADES
\end{abstract}

by

\title{
Robin Elizabeth Sarabia
}

Florida International University, 2012

Miami, Florida

Professor Michael Heithaus, Major Professor

Bottlenose dolphins (Tursiops truncatus) are large-bodied predators that are locally abundant in the coastal Everglades. Because of their potential to exert strong top-down effects on their communities, it is important to understand how spatiotemporal variation in biotic and abiotic factors affects the abundance and behavior of dolphins. This study combined two years of transect surveys with photographic identification methods to assess spatiotemporal variation in the abundance and group sizes of bottlenose dolphins across four large regions of the coastal Everglades including the Shark and Harney Rivers, Whitewater Bay, and coastal oceans of the Gulf of Mexico and Florida Bay. Dolphin abundance was similar across wet and dry seasons, except in river habitats where abundances were higher during the dry season. Group sizes were largest in Florida Bay and open water. Dolphins may be relatively resilient to abiotic changes in the coastal Everglades, with the possible exception of river habitats. 


\section{TABLE OF CONTENTS}

CHAPTER

PAGE

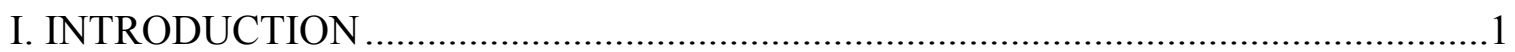

Issues and work in the Coastal Everglades ..................................................

Importance of dolphins in an ecosystem................................................... 2

Dolphin habitat use ...............................................................................4

Dolphin social structure ...........................................................................

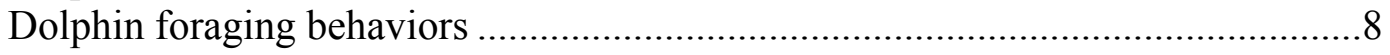

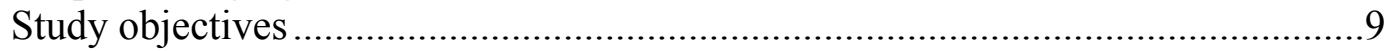

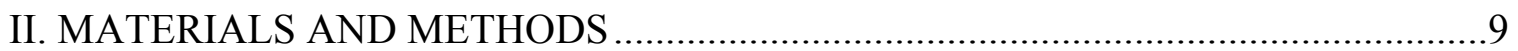

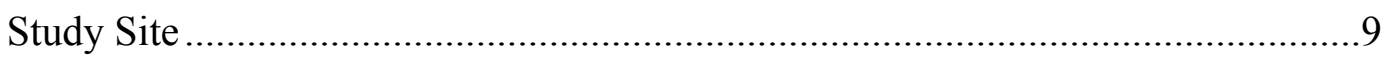

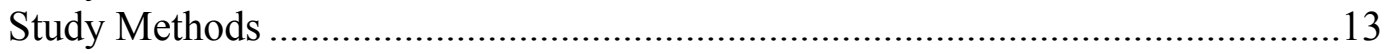

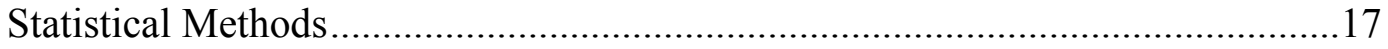

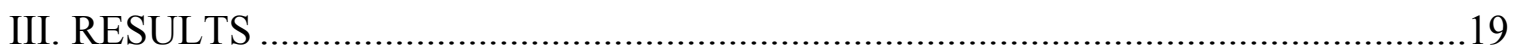

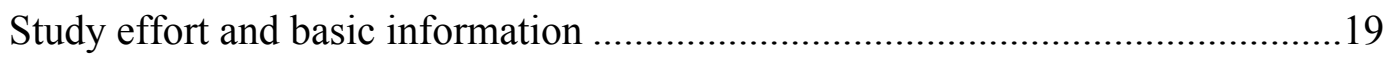

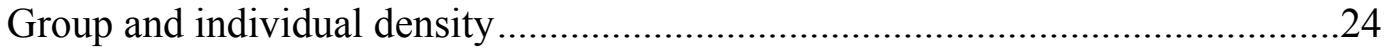

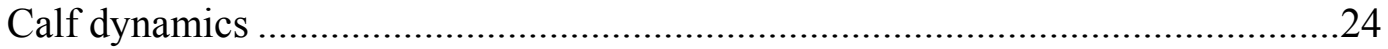

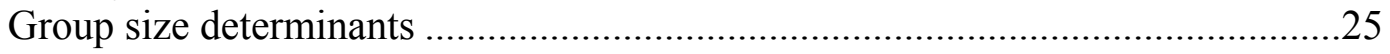

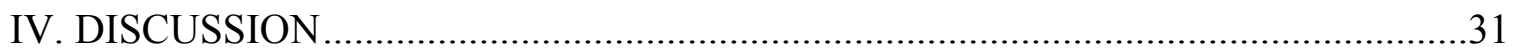

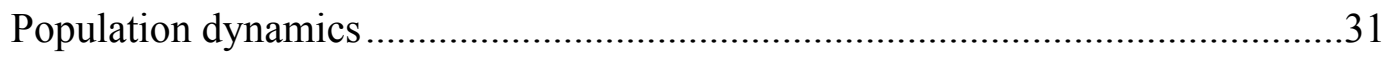

Spatial variation

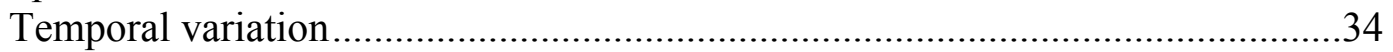

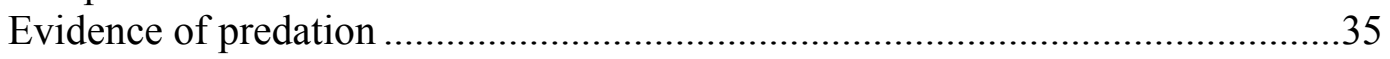

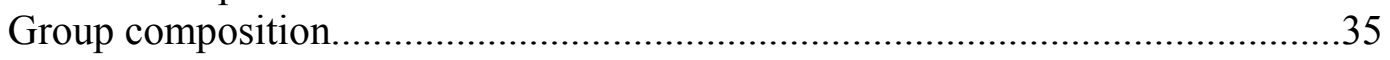

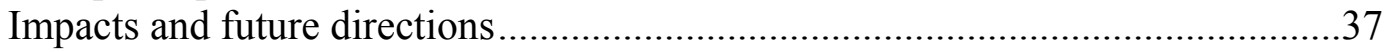

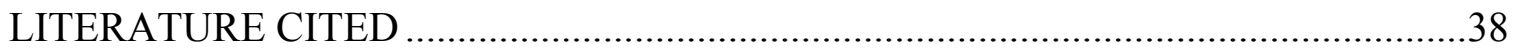




\section{LIST OF FIGURES}

FIGURE

PAGE

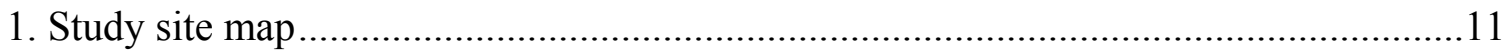

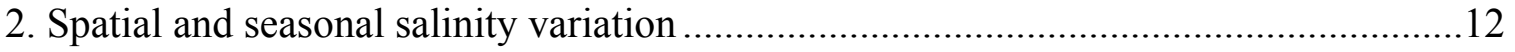

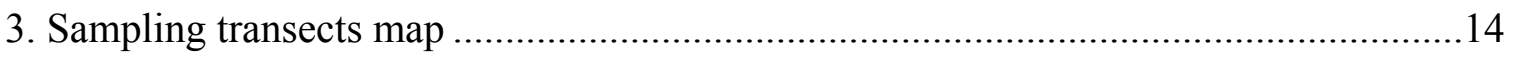

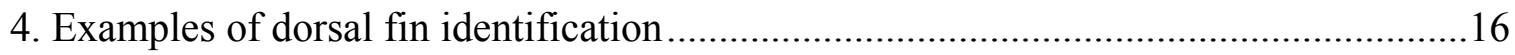

5 a. Identification of unique animals in Whitewater Bay ...........................................23

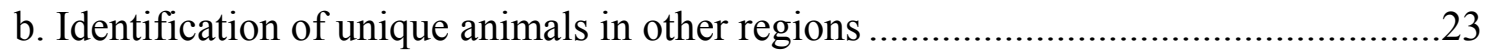

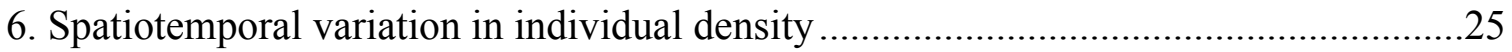

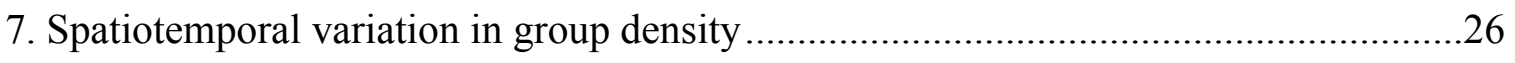

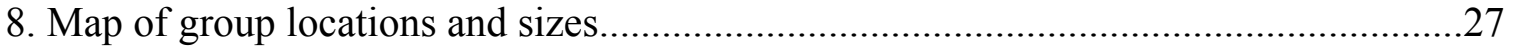

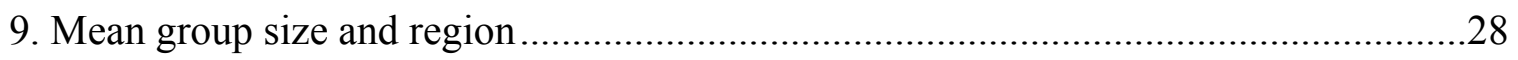

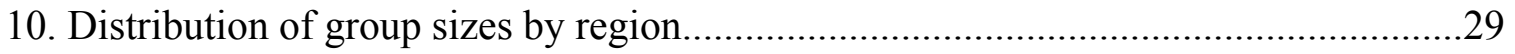

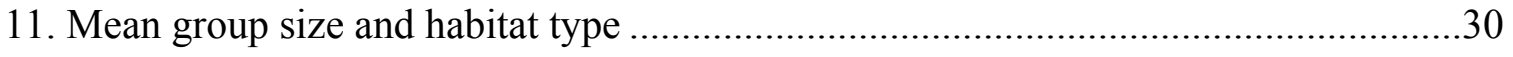

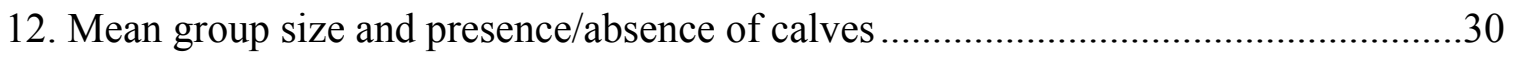




\section{INTRODUCTION}

The Florida Everglades is a system of subtropical wetlands comprising a number of distinct habitats that terminates in oligotrophic mangrove estuaries adjacent to Florida Bay and the Gulf of Mexico (Childers 2006). Within the coastal Everglades, there is an assemblage of multiple, distinct aquatic habitats including sloughs, creeks, rivers, shallow bays with mangrove islands, and coastal oceans. Urbanization of the surrounding land and global climate change have reduced freshwater flow in volume and duration, thus changing patterns of dissolved oxygen, salinity, primary production, and consequently the distribution of many species of consumers (e.g., Turner et al. 1999, Chick et al. 2004, Rehage and Trexler 2006). Diminished freshwater flow that has resulted from anthropogenic activities has reduced fish populations, and in turn, limited populations of some upper trophic level predators (e.g., wading birds) though decreased food availability (Lorenz and Serafy 2006, Trexler and Goss 2009).

The Comprehensive Everglades Restoration Plan (CERP) was created to restore and preserve the natural water function and resources by capturing fresh water that now flows to the Atlantic Ocean and the Gulf of Mexico and redirecting it back to the Everglades (see CERP: evergladesplan.org). The project, budgeted at $\$ 7.8$ billion, will result in considerable changes throughout the Everglades, including in the coastal estuaries (Perry 2004, Davis et al. 2005, Gaiser 2009). In order to predict and understand the impact this will have on native species, as well as to assess the quality of "restoration," it is critical to have a functional understanding of how spatiotemporal variation in biotic and abiotic factors, and their interaction, affects the abundance and behavior of key species. 
Most published studies of Everglades ecosystems, especially in coastal estuaries, has focused on organisms at relatively low trophic levels (e.g., Trexler et al. 2005, Williams and Trexler 2006; but see Wiley and Simpfendorfer 2007, Heithaus et al. 2009, Mazzotti et al. 2009 for studes of large predators). The oligohaline ecotone region, however, is predicted to be dramatically affected by habitat restoration and sea level rise because of drastic changes in abiotic conditions. Thus, an understanding of how these changes will impact upper trophic level species, and their roles in estuarine communities and ecosystems, is important. Previous work on large predators in the coastal Everglades has suggested that they may play an important role in upstream transport of marine-derived nutrients into the oligohaline ecotone (e.g.,, Matich et al. 2011, Rosenblatt and Heithaus 2011). However, the predators that have been studied - bull sharks (Carcharhinus leucas) and alligators (Alligator mississipiensis) - are poikilothermic and have low metabolic rates (Coulson et al. 1989, Schmid and Murru 1994), particularly when compared to mammalian metabolism. Consequently, the overall ecological impacts of these species through consumptive effects may not be as sizeable as those of abundant mammalian predators.

Bottlenose dolphins (Tursiops truncatus) are large-bodied predators that can be locally abundant in coastal and estuarine habitats (Ballance 1992), including those of South Florida. They have high metabolic rates, and may consume a large percentage of total productivity, potentially impose strong top-down effects on community structure through direct predation (Bowen 1997, Young and Phillips 2002, Williams et al. 2004), and may serve as an indicator of ecosystem health (Torres and Urban 2005.) Therefore, 
understanding spatiotemporal variation in the abundance of dolphins and their feeding ecology in the coastal Everglades is important for elucidating the dynamics of the ecosystem and for successful management of this system. However, no previous work on dolphins in the inshore waters of the coastal Everglades has been published, and their trophic relationships and ecological roles are poorly known in the area. Currently available data on dolphins within the boundaries of the Everglades National Park come from studies conducted in the marine waters of Florida Bay (Torres 2007, Torres et al. 2008) and are focused on marine habitat affinities of dolphins. Furthermore, the current NOAA Marine Mammal Stock Assessment examines only the bottlenose dolphins residing in Florida Bay and does not consider the potential role dolphins may play in the trophic dynamics and nutrient flow of the more inshore waters of the coastal Everglades (NOAA 2010). The last known descriptions of dolphins within the estuarine Everglades are sporadic notes on dolphin distribution from the early 1950's (Moore 1953).

Bottlenose dolphins are capable of rapid long-distance movements. For example, Wells et al. (1999) recorded one animal that moved 4,200 $\mathrm{km}$ in 47 days. Therefore, they could serve as mobile links between ecosystems, although not all populations or individuals display such pronounced distributions. Indeed, many populations in the waters of the southeastern United States tend to display high site fidelity and what may initially appear to be a continuous coastal distribution is often a mosaic of localized resident groups with limited population exchange among these groups (Irvine et al. 1981, Gubbins 2002, Irwin and Würsig 2004). In extreme cases, two or more genetically separate populations that differ in foraging ecology may be sympatric (Fernandez et al. 2011). Home range sizes, 
however, can vary greatly. In some populations, individuals may occupy areas as small as $0.4 \mathrm{~km}^{2}$ while others exhibit movements across more than $2000 \mathrm{~km}$ (e.g., Caldwell 1955, Bassos 1993). In Sarasota Bay, Florida, USA the approximately 100 resident animals have a year-round community home range of about $125 \mathrm{~km}^{2}$, comprised of the overlapping core areas of different groups and individuals (Wells 1993). Their distribution is often correlated with environmental factors, but the nature and strength of the relationship is confounded with fish distribution and is difficult to critically assess (Allen et al. 2001, Torres et al. 2008). For example, dolphin distributions in Florida Bay are more tightly correlated with environmental characteristics than measures of prey distribution based on otter trawls (Torres and Read 2008).

Habitat preferences of dolphins have been studied in multiple locations around the world. Food availability, predation risk, social and maternal factors, as well as abiotic conditions have been identified as potential drivers, with their relative importance varying within and among study locations (Wells 1993, Heithaus and Dill 2002, Torres et al. 2008, Yeates and Houser 2008, McHugh et al. 2011a). Changes in habitat use and abundance of dolphins within locations can be driven by numerous factors tidal variation (Gregory and Rowden 2001), the interaction of submarine characteristics with foraging tactics and seasonally abundant prey (Hastie et al. 2004), overall prey availability (Shane et al. 1986, Heithaus et al. 2002), predation risk (Heithaus and Dill 2002, 2006) or environmental factors including dissolved oxygen, salinity, turbidity and temperature (Barco et al. 1999, Wilson et al. 1997, Stocktin et al. 2006, Miller and Baltz 2010). The extent to which some of these relationships are causal, particularly for physical and abiotic drivers, 
remains poorly understood. For example, physical characteristics may indirectly affect dolphins through their impacts on the abundance and distribution of dolphin predators and prey (e.g., Toth et al. 2011).

Even in adjacent areas, the drivers of temporal and spatial variation in abundance can differ; such as in New South Wales, Australia, where tidal phase and an interaction of season and tidal phase influence dolphins habitat use in the Clarence River, but neither tidal phase nor season influences spatial distributions in the nearby Richmond River (Fury and Harrison 2011). The degree to which various factors shape dolphin abundances, therefore, likely is context-dependent. Some of this context dependence may be driven by the extent to which spatial and temporal variation in dolphin abundance is the result of spatial shifts within home ranges versus immigration and emigration of individuals. Such dynamics, however, are poorly understood in many dolphin populations (e.g., Stocktin et al. 2006, Wilson et al. 1997).

Group size is one of the main defining characteristics of social organization of a population (Wilson 1975). In cetaceans, group sizes vary considerably within and among species and populations. Like other taxa, grouping patterns are influenced by the abundance and predictability of resources as well as predation risk (See Gowans et al. 2008 for a summary). Larger group sizes are favored when predation risk is higher, grouping can enhance resource acquisition of individuals, and clumping of resources promotes social coexistence (e.g., Alexander 1974, Bertram 1978). Group sizes, however, are mediated by costs such as increased probabilities of predator and parasite encounter 
and resource competition (Bertram 1978). For coastal populations of bottlenose dolphins, group sizes are typically smaller where the habitat is complex and resources are predictable (e.g., Campbell et al. 2002) and larger in open water with unpredictable and spatially fluctuating resources (e.g., Defran and Weller 1999). Importantly, because of the high mobility and relatively low energetic cost of travel to dolphins, group sizes and composition can be highly dynamic on scales of hours or even less (e.g., Connor et al. 2001). Thus, individuals can select appropriate group sizes and compositions on the basis of current requirements (i.e., behavioral state) or in response to changing trade-offs through ontogeny or across sex and reproductive states.

Social structure is one of the best-studied aspects of bottlenose dolphin behavior, and varies considerably between regions in response to environmental and social factors (e.g., Connor et al. 2000). In Sarasota Bay, a residential inshore population is typified by fluid groups largely defined by age and sex (Wells et al. 1987, Wells 1991, Curry and Smith 1997, Barros et al. 2010). The most common types of groups include juvenile bands, male pairs/trios, and nursery bands comprised of females of multiple generations and calves as well as older calves of both sexes. Nursery groups tend to include females with long-term associations that share home ranges, although the composition of these groups is highly variable (Wells et al. 1987). Subadult groups are formed by juveniles of both sexes and individuals remain in these groups for many years, often over a decade (Wells et al. 1987). Roving male pairs/trios are long-term, stable associations capable of lasting for decades, although some males are largely solitary (Wells et al. 1987, Wells 1991). These groups select different parts of the population's home range; females in nursery 
bands select protected shallow-waters much more often than subadults or males (Wells 1993).

In contrast to Sarasota Bay, in Shark Bay, Western Australia, male Indo-Pacific bottlenose dolphins may form pairs and trios that are part of a large, multi-level male alliance system or be a part of larger "superalliances" that are one of the most complex non-human societies (Connor et al. 1992, 1999). Also, female groups appear to be more fluid in Shark Bay than those in Sarasota Bay (Smolker et al. 1992). In comparison to Sarasota Bay females' selection of safer habitats for nursery groups, females in Shark Bay may switch habitats adaptively to take advantage of both safer resting habitats and more energetically profitable but riskier foraging habitats (Heithaus and Dill 2002). Unlike these sex- and maturity-defined group structures, common bottlenose dolphins in Moray Firth, Scotland, exhibit groups composed of both adults of both sexes with no preferential associations among males (Wilson et al. 1997).

It is critical to note that the social structure of dolphins may be dynamic as environmental conditions change. For example, in Moreton Bay, Australia, changes in food sources led to shifts in social structure with dolphins shifting from two separate sympatric communities to a more integrated single society with smaller groups sizes, different patterns of association, and different foraging patterns as one of the food sources became less available (Ansmann et al. 2012). 
Bottlenose dolphins also display considerable variation in foraging behavior within and among populations. Indeed, even within populations innovative foraging tactics arise, apparently in response to ecological conditions, and often are maintained through social learning (Connor 2001, Krutzen et al. 2005, Sargeant et al. 2007). Some foraging behaviors are specific to the local environment; for example, dolphins in Shark Bay have been observed using marine sponges as foraging tools; sponging is the predominant mode of foraging for some individuals, but is only used by a small number of individuals with the behavior being passed down through matrilines (Mann et al. 2008). Similar tactical variation has been observed in Florida Bay. Three distinct foraging methods have been observed - deep diving, which is a common tactic in multiple populations, a herd-andchase tactic in which a barrier such as a mud-bank or mangrove island is used to herd the fish, and mud-ring feeding, a foraging behavior never observed elsewhere and requiring the cooperation of multiple individuals (Torres and Read 2009). Each tactic is correlated with a particular habitat type and location in the bay, varying with depth and bathymetric features; dolphins appear to limit their overall movements to coincide with the habitats predicted by their preferred tactic (Torres and Read 2009). Of particular interest are the site-specific "mud-plume" strategy (Lewis and Schroeder 2003) and the similar "mudring" feeding behavior (Torres and Read 2009), which are thought to be unique to south Florida. Other behaviors are seen across many populations, such as the use of shallow mud-flats for intentional stranding to capture prey herded onto the bank (Silber and Fertl 1995). Both environmental heterogeneity (Sargeant et al. 2007) and unexploited niches (Patterson and Mann 2011) have been postulated to lead to the development of new and unique foraging behaviors. 
Prey selection by dolphins appears to be a function of both prey availability and behavioral tactics being employed by dolphins. Dolphins using inland waters bordering the Gulf of Mexico often feed heavily on common seagrass-associated fish, particularly larger, solitary, soniferous fish (Barros and Wells 1998, Gannon et al. 2005, McCabe et al. 2010.) It is believed that this preference reflects a passive listening foraging tactic (Gannon et al. 2005). Variation in foraging tactics may reflect differences in preferred prey. For example, mud-ring feeding in the Florida Keys appears to exclusively target mullet (Lewis and Schroeder 2003).

The objective of my study was to conduct preliminary investigations of spatiotemporal variation in the abundance and behavior of bottlenose dolphins in the Florida Coastal Everglades in order to gain insights into their potential ecological roles. Specifically, I estimated the number of individual dolphins using different regions of the FCE, investigated spatial and temporal variation in dolphin densities and group sizes, and conducted preliminary investigations into spatial variation in group composition and age/sex classes.

\section{MATERIALS AND METHODS}

$\underline{\text { Study site }}$

The Florida Coastal Everglades is a spatially and temporally heterogeneous system which extends from small creeks where freshwater marshes transition to mangrove forests through mangrove-lined channels and inland bays to the coastal oceans of the Gulf of Mexico and Florida Bay (Childers 2006). The system is relatively oligotraophic and 
phosphorous-limited. Phosphorous inpts in this estuary have a marine source, rather than a terrestrial one, creating an "upside down" estuary with no productivity peak in the oligohaline zone (Childers et al. 2006). Instead, productivity decreases from the mouths of rivers to upstream marshes. Salinity varies both spatially and temporally as the region alternates between a high precipitation wet season (July - December) and a low precipitation dry season (January - June) (Schomer and Drew 1982). During the dry season, salinities measuring $>20$ ppt may occur up to $17 \mathrm{~km}$ from the mouth of the estuary (Rosenblatt and Heithaus 2011) while salinities where the channels meet the coastal oceans can fall to $<15 \mathrm{ppt}$ in the wet season (Childers et al. 2006). Seasonal changes in precipitation lead to marked spatiotemporal variation in aquatic communities. Fish from freshwater marshes enter creeks and channels during marsh dry down creating a pulse of increased prey availability to estuarine predators (Rehage and Loftus 2007).

My study was conducted from July 2010 - June 2012 in five major areas of the Everglades National Park: 1) Whitewater Bay, 2) Joe River, 3) Shark River Slough from Tarpon Bay to the mouths of the Harney and Shark Rivers, 4) coastal waters of Ponce de Leon Bay and a strip up to $4 \mathrm{~km}$ offshore and extending south to Cape Sable ("Gulf of Mexico"), and 5) the northernmost portion of Florida Bay extending from Flamingo to Cape Sable (See Figure 1). 


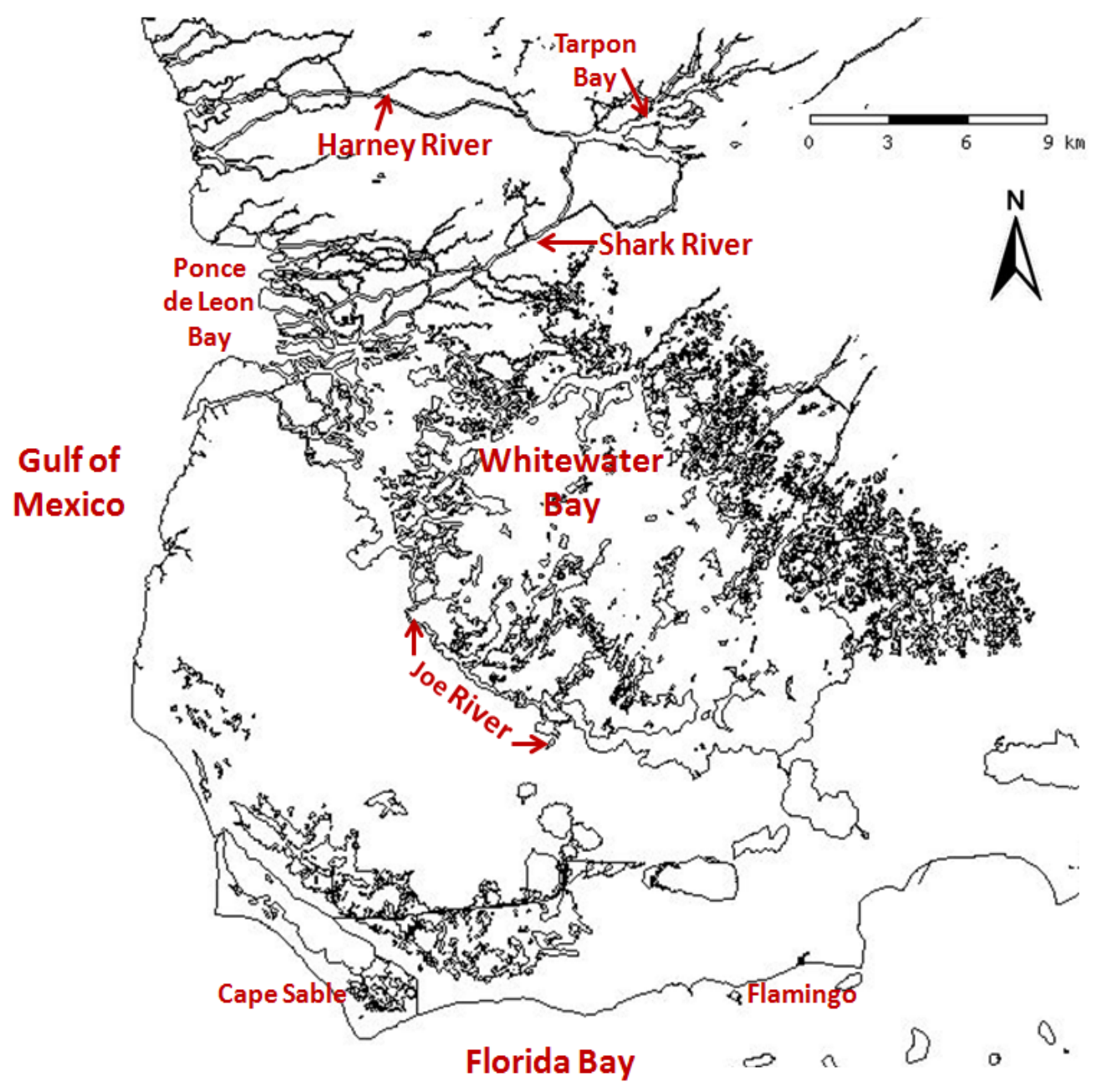

Figure 1: The study was conducted in the coastal and inland waters of southwest Florida's coastal Everglades. Transects were conducted in the Shark and Harney Rivers, Joe River, Whitewater Bay, the Gulf of Mexico, and Florida Bay. 
Whitewater Bay is a large (approximately $200 \mathrm{~km}^{2}$ ) and shallow enclosed bay with relatively uniform depth $(0.75-1.75 \mathrm{~m}$,$) and characterized by small tidal variation.$ Salinities were observed to range from 33 ppt in the wet season to as low as 5 ppt in the dry season (R. Sarabia, unpublished data). A number of small red mangrove (Rhizophora mangle) islands of varying sizes are scattered throughout the bay and water clarity varies with location in the bay. The Shark and Harney Rivers are comprised of deeper water channels (2.5-4.5 meters deep, with an average width of 100 meters) lined with mangroves and a salinity gradient ranging from marine levels of up to $35 \mathrm{ppt}$ at the river mouth to values as low as $<4$ ppt in Tarpon Bay. Tarpon Bay is a narrow (100-500 meters), shallow (1-2 meters), mangrove-lined bay bordering the sawgrass ecotone (Figure 2), and was the upriver terminus for this study.

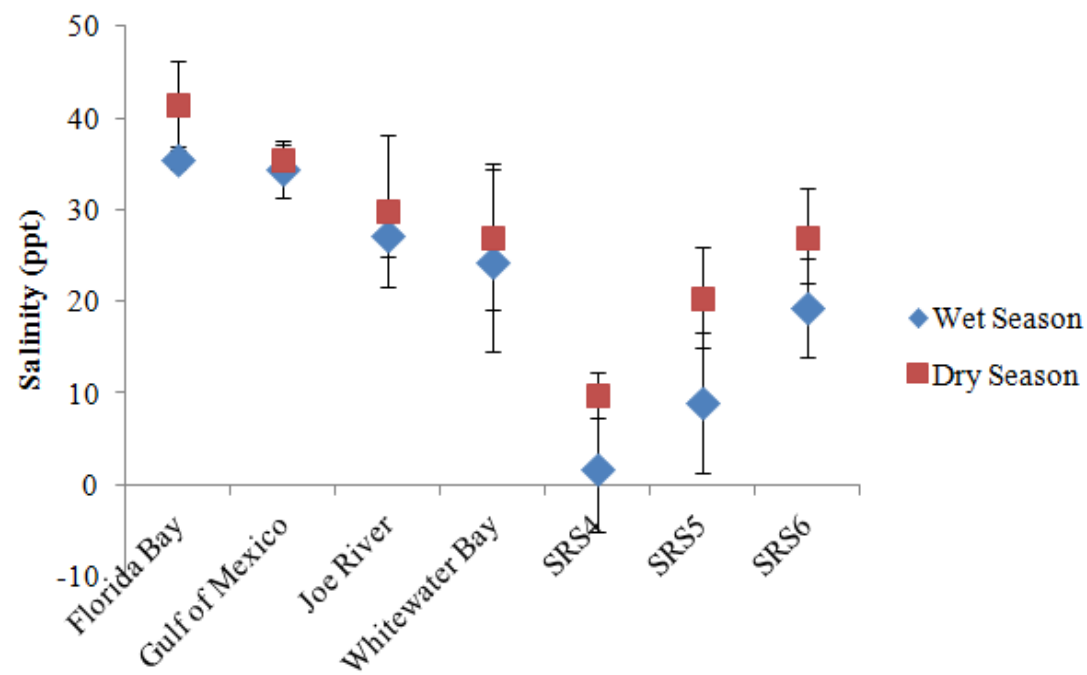

Figure 2: Spatial and seasonal variation in salinity in the study system. SRS 4, 5 and 6 are monitoring stations in the Shark River, with SRS4 being the furthest upstream and SRS6 being the furthest downstream. Other data were taken by the author during the course of this study. Error bars show standard error. 
Florida Bay is a shallow basin, connected to the Gulf of Mexico at its western margin and to the Straits of Florida to the south through multiple channels between the islands of the Florida Keys. Mean salinity during the dry season can exceed $40 \mathrm{ppt}$ in the areas surveyed (Boyer et al. 1997). Water clarity, depth and benthic habitats vary regionally; the area covered by this study is characterized by a muddy bottom, very turbid water and depths ranging from 0.5 to 3 meters (Torres and Read 2009).

\section{$\underline{\text { Study Methods }}$}

I established transects in five regions (three estuarine, two in the coastal ocean), including Whitewater Bay (55 km in length), the Shark and Harney Rivers and Ponce de Leon Bay (50 km), Joe River (20 km), coastal waters of the Gulf of Mexico (33 km) and Florida Bay $(15 \mathrm{~km})$ (Figure 3). Transects were run onboard a $6.4 \mathrm{~m}$ vessel with three trained observers. Transects were run at $15 \mathrm{kph}$ and only in Beaufort sea conditions 3 or less. 


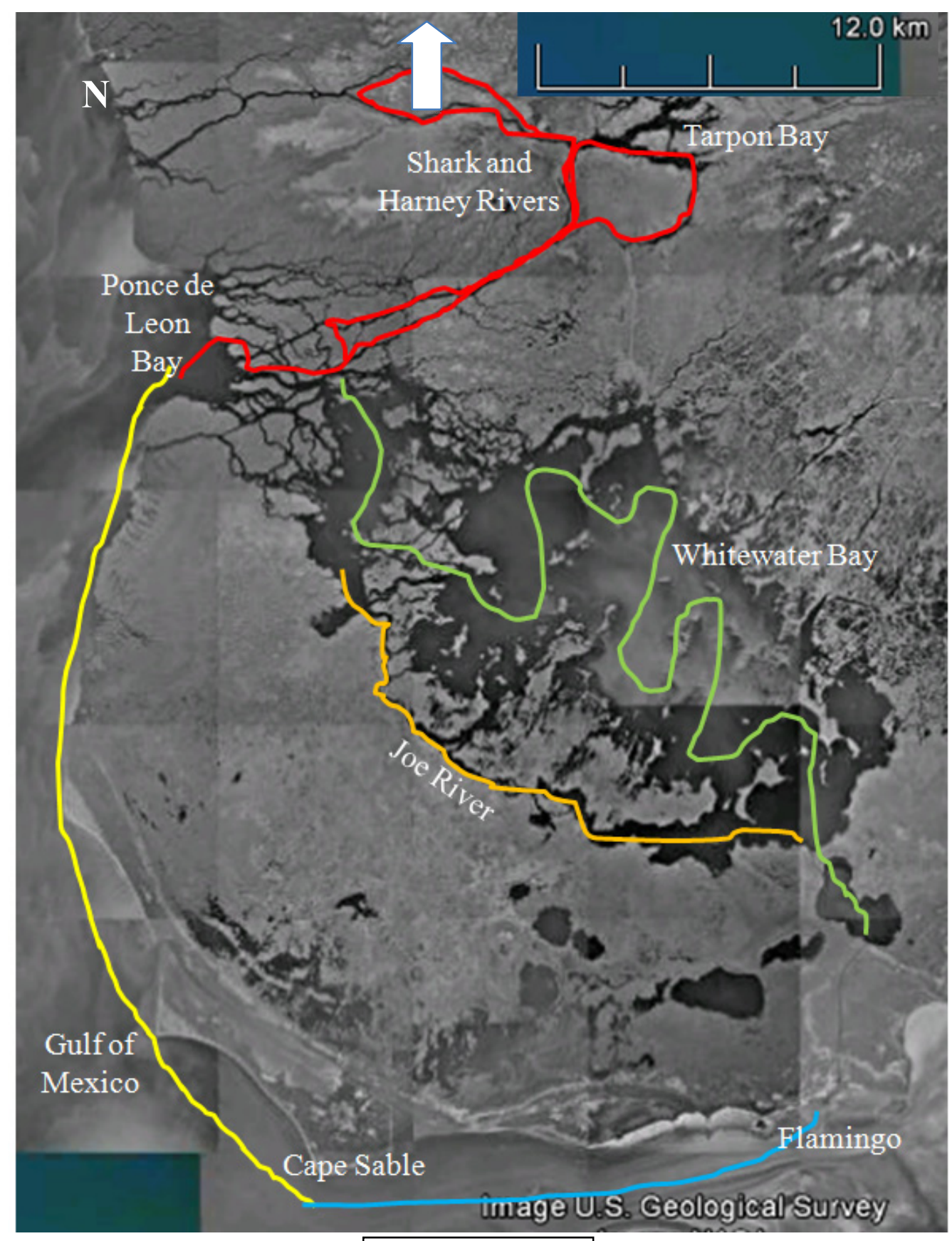

\begin{tabular}{|r|}
\hline Transect Lines \\
Florida Bay \\
Gulf of Mexico \\
Joe River \\
Shark/Harney Rivers \\
Whitewater Bay
\end{tabular}

Figure 3 - Location of sampling transects in the Florida Coastal Everglades. Image from Google Earth 6.1 
When a dolphin group was encountered during a transect, I marked the location on the transect and left the transect to survey the group. For the purposes of this study, a group was defined as all animals in close proximity to one another $(<100 \mathrm{~m})$ engaged in similar behaviors (Shane 1990). During the survey, I recorded the group GPS position, environmental conditions (salinity, water temperature, dissolved oxygen, Beaufort sea state, tidal conditions, water depth and habitat type), behavior, and group size. Due to equipment malfunctions I was unable to record salinity, water temperature, and dissolved oxygen for some surveys. Predominate group behavior was determined at first sighting and categorized according to a modification of the Sarasota Bay Research Program guidelines (e.g., McHugh et al. 2011b). Traveling dolphins were those seen surfacing with persistent directional movement and surfacing at regular intervals. Resting dolphins were observed at or near the surface but not engaged in any obvious surface behavior, exhibited slow movements, and often occurred in tight groups. Socializing dolphins were those observed chasing or making bodily contact with one another, including a suite of possible behaviors linked with play and/or mating. Foraging dolphins were those observed making any effort to capture prey. Behaviors included, but were not limited to, tail-out grubbing in the mud, herding prey, chasing prey, and rapid surfacing at varying intervals with no consistent heading. If the dolphins were first observed reacting to the presence of the researchers (e.g., approaching the boat to bow ride), their behavior was classified as unknown.

I took photographs of the dorsal fins of every individual in a group using a Canon EOS 10D SLR. These photos were used to create a catalog of dorsal fins to identify 
individuals on the basis of variation in dorsal fin size and shape, along with the nicks and scars acquired though the animal's lifetime (e.g.,, Wursig and Wursig 1977) (Figure 4). The catalog was continuously updated with new individuals and current photographs of the animals, and all new photographs were compared to the catalog for identification.
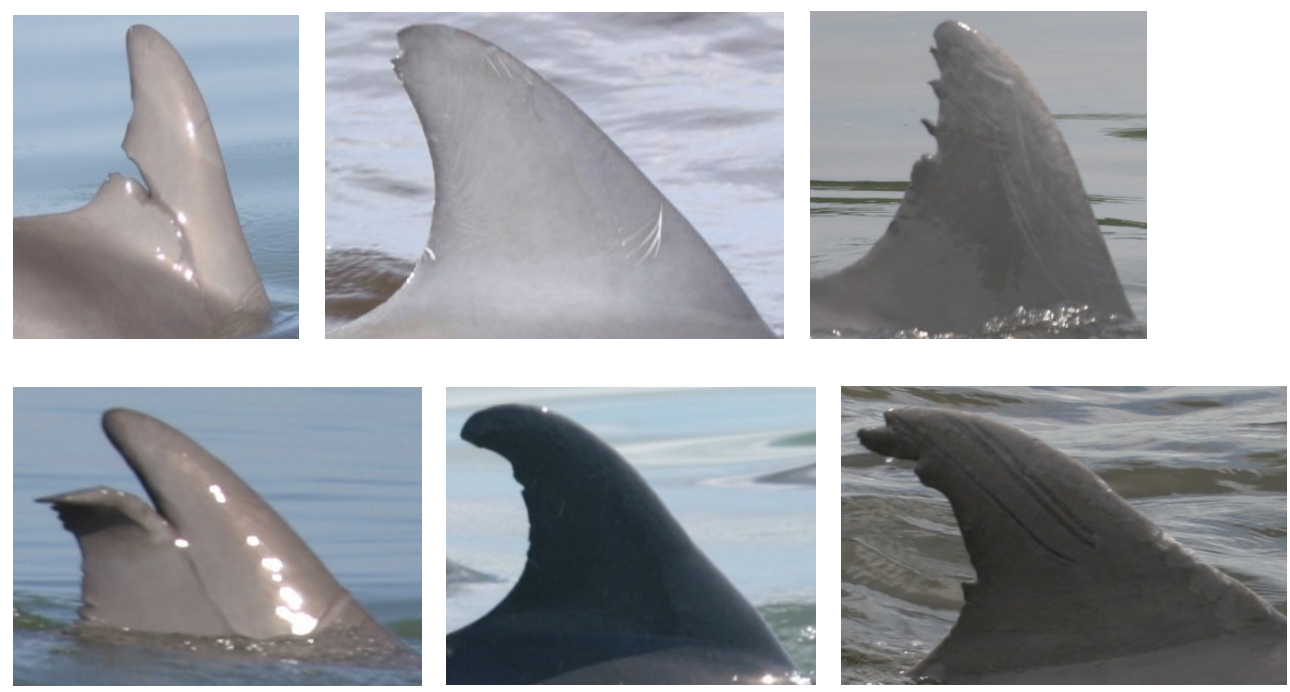

Figure 4: Examples of distinctive dorsal fin morphology and markings allowing for consistent identification of individuals through time.

Photographs from each sighting were sorted by individual and all the photographs of an individual from a given sighting were then sorted to obtain the highest quality picture for comparison to the catalog. The sex of individuals was determined opportunistically, either by observing the presence of a dependent calf in the echelon position with a particular animal during multiple surveys (e.g., Elliser and Herzing 2011) or by directly observing the external genitalia. Calves were identified by size and behavior and sorted into three categories: juveniles, calves, and neonates. Juveniles were defined as animals smaller than adult size but greater than half an adult body length. A calf was defined as 
an animal smaller than half an adult body length, and was typically found closely associated with its mother, particularly while surfacing. Neonates were identified by the presence of visible fetal folds and stereotypical awkward surfacing during breathing (e.g. Shane 2004).

Photographs were also used to examine individuals for evidence of scars from shark bites. Scars were considered to have been inflicted by sharks in they were characteristically crescent-shaped or had deep and widely spaced tooth marks (Heithaus 2001.) I determined the proportion of individuals with wounds by comparing the number of known individuals with wounds to the total number of individuals identified. This method underestimates actual wounding rates since only a small portion of the body is surveyed for evidence of shark bites (e.g., Heithaus 2001).

\section{$\underline{\text { Statistical Methods }}$}

Statistical tests were carried out using JMP Pro $9^{\mathrm{TM}}$ software. To test for adequate sampling, a rarefaction analysis was performed. Cumulative individual curves were generated by resampling group compositions for 1000 randomly selected groups to calculate a mean and variability estimate of the cumulative number of individuals for each group. This mean cumulative number of individuals was then plotted against the randomly pooled number of groups; a linear regression was then performed on the last four points to determine if the slope of the line was significantly different from zero (e.g., Bizzarro et al. 2007). 
To determine spatial and temporal variation in dolphin abundance, I calculated both the densities of groups (number of group sightings per $\mathrm{km}^{2}$ ) and individuals (number of individual animals per $\mathrm{km}^{2}$ ). Area sampled was calculated by multiplying transect length by $0.8 \mathrm{~km}$, which represents sightings within 400 meters of the boat (the distance at which groups were sighted during a sea state of Beaufort 3). Because all of the channels sampled were narrower than $0.8 \mathrm{~km}$, instead of $0.8 \mathrm{~km}$, a mean width was calculated by averaging channel width derived from measurements every $100 \mathrm{~m}$ along transects. Data were non-normal and transformations were unsuccessful, necessitating the use of nonparametric statistical methods (Kruskal-Wallis and Mann Whitney tests). To determine if dolphins preferentially used areas near mangrove islands in Florida Bay, I used logistic regression to compare the probability of encountering a group within 100 meters of a mangrove island relative to that more than $100 \mathrm{~m}$ from islands.

Because of the turbidity of water in most sampling regions, I calculated group size using the total number of unique individuals photographed during a sample and estimates of minimum group size (i.e., number of individuals surfacing simultaneously). These data were also non-normal, and no transformations successful. Therefore, I used a series of Kruskal-Wallis tests to investigate the effects of season (Wet or Dry), group composition (the presence or absence of calves), behavior (at first sighting), and region. For tests showing significant effects, Mann-Whitney tests were used to determine statistically significant paired contrasts where necessary. 
The distance a group was found upstream in the Shark and Harney Rivers was calculated as river distance from a central point in Ponce de Leon Bay. We used Kruskal-Wallis tests to investigate whether dolphins moved further upstream during particular seasons or if particular age/sex classes were more likely to be encountered further upstream. A series of Kruskal-Wallis tests were used to examine the proportion of calves encountered per total individuals sampled by season, region, behavior, and distance upstream. A simple logistic regression was performed to test if group encounter rate was higher within $100 \mathrm{~m}$ of mangrove islands.

\section{RESULTS}

From August 2010 - June 2012, I completed a total of 67 transects (34 in the dry season, 33 in the wet season). These transects involved over 268 hours of observation and covered $c a .2650$ kilometers (Table 1). Overall, I encountered 148 groups, 34 of which were foraging, 14 were socializing, and 63 were traveling. I was not able to determine the behavior of 27 groups. Resting groups of dolphins were not observed. Multiple foraging behaviors were observed; the most common behavior was a tail-out mud grubbing behavior that was observed on 15 occasions, while using mangrove roots to herd fish was observed on seven occasions. Although not observed during quantitative sampling, intentional stranding on mud banks was observed near the mouth of the Harney River.

I recorded over 12,000 photographs that resulted in identifying 174 unique individuals. A total of 31 animals were identified in Florida Bay, 30 in the Gulf of Mexico, 9 in the 
Shark and Harney Rivers, and 92 in Whitewater Bay. All 14 individuals identified in Joe River were also observed in Whitewater Bay. Three animals were observed using both Whitewater Bay and the Shark River, four were observed using both the coastal ocean and either Whitewater Bay or Shark River, and two animals were observed in both Florida Bay and the Gulf of Mexico. No animals from the estuary were observed in Florida Bay or vice versa. Juveniles were observed on 51 occasions, calves on 17 occasions, and neonates were sighted only twice. Most calves were not cataloged as individuals, because of a lack of identifying features early in life. Definitive shark bite scars were observed on two individuals, with possible bites occurring on seven others resulting in a minimum estimate of $1-5 \%$ of the population having been bitten by sharks along their dorsal surfaces.

Rarefaction analysis showed that the identification rate of new individuals in Whitewater Bay has reached an asymptote with a slope nonsignificantly different from zero, showing that the region was sampled sufficiently to capture most of the individuals using this habitats (Figure 5). However, all of the other subregions (Joe River, the Shark and Harney Rivers, Florida Bay and the Gulf of Mexico) had rates of identification of new animals significantly different from zero, indication that these regions were not surveyed sufficiently to identify a large proportion of the individuals in the area (Figure 5). Given the small sampling area relative to the likely size of individual dolphin home ranges in these areas, this result is not surprising. However, when the rarefaction analysis was performed, only the analysis of all individuals from all regions showed a slope nonsignificantly different from zero, indicating adequate sampling $(\mathrm{p}=0.188)$. The slopes 
of the identification rates of new individuals in Florida Bay $(p=0.0005)$, the Gulf of Mexico $(p=0.020)$, Joe River $(p=0.005)$ and the Shark and Harney Rivers $(p=0.0004)$ were all significantly different from zero, indicating that new individuals were still being discovered. The identification rate of new individuals in Whitewater Bay was borderline significant $(\mathrm{p}=0.046)$. 
Table 1.Seasonal and regional survey effort and dolphin sightings.

\begin{tabular}{|c|c|c|c|c|c|c|c|}
\hline \multirow[b]{2}{*}{ Transect } & & \multirow[b]{2}{*}{ \# transects } & \multirow[b]{2}{*}{ \# dolphins } & \multirow[b]{2}{*}{ \# of Groups } & \multicolumn{2}{|c|}{ Group Size } & \multirow[b]{2}{*}{$\%$ Calf } \\
\hline & & & & & Mean \pm SD & Range & \\
\hline \multirow[t]{3}{*}{ Florida Bay } & & 7 & 89 & 7 & $12.71 \pm 9.59$ & $2-31$ & 8.73 \\
\hline & Dry & 4 & 32 & 4 & $8.0 \pm 6.48$ & $2-17$ & 11.25 \\
\hline & Wet & 3 & 57 & 3 & $19 \pm 10.44$ & $12-31$ & 5.38 \\
\hline \multirow[t]{3}{*}{ Gulf of Mexico } & & 10 & 69 & 13 & $5.31 \pm 4.70$ & $1-15$ & 5.17 \\
\hline & Dry & 6 & 63 & 10 & $6.3 \pm 4.90$ & $1-15$ & 6.72 \\
\hline & Wet & 4 & 6 & 3 & $2.0 \pm 1.73$ & $1-4$ & 0 \\
\hline \multirow[t]{3}{*}{ Joe River } & & 12 & 97 & 26 & $3.73 \pm 2.75$ & $1-12$ & 9.57 \\
\hline & Dry & 6 & 54 & 13 & $4.15 \pm 3.28$ & $1-12$ & 8.54 \\
\hline & Wet & 6 & 43 & 13 & $3.31 \pm 2.13$ & $1-9$ & 10.51 \\
\hline \multirow[t]{3}{*}{ Shark/Harney Rivers } & & 16 & 42 & 20 & $2.1 \pm 1.65$ & $1-6$ & 4.25 \\
\hline & Dry & 9 & 27 & 11 & $2.45 \pm 1.63$ & $1-5$ & 7.08 \\
\hline & Wet & 7 & 15 & 9 & $1.67 \pm 1.65$ & $1-6$ & 0 \\
\hline \multirow[t]{3}{*}{ Whitewater Bay } & & 22 & 454 & 82 & $5.54 \pm 4.05$ & $1-18$ & 8.81 \\
\hline & Dry & 9 & 188 & 33 & $5.69 \pm 4.72$ & $1-18$ & 9.56 \\
\hline & Wet & 13 & 266 & 49 & $5.42 \pm 3.57$ & $1-8$ & 8.37 \\
\hline
\end{tabular}



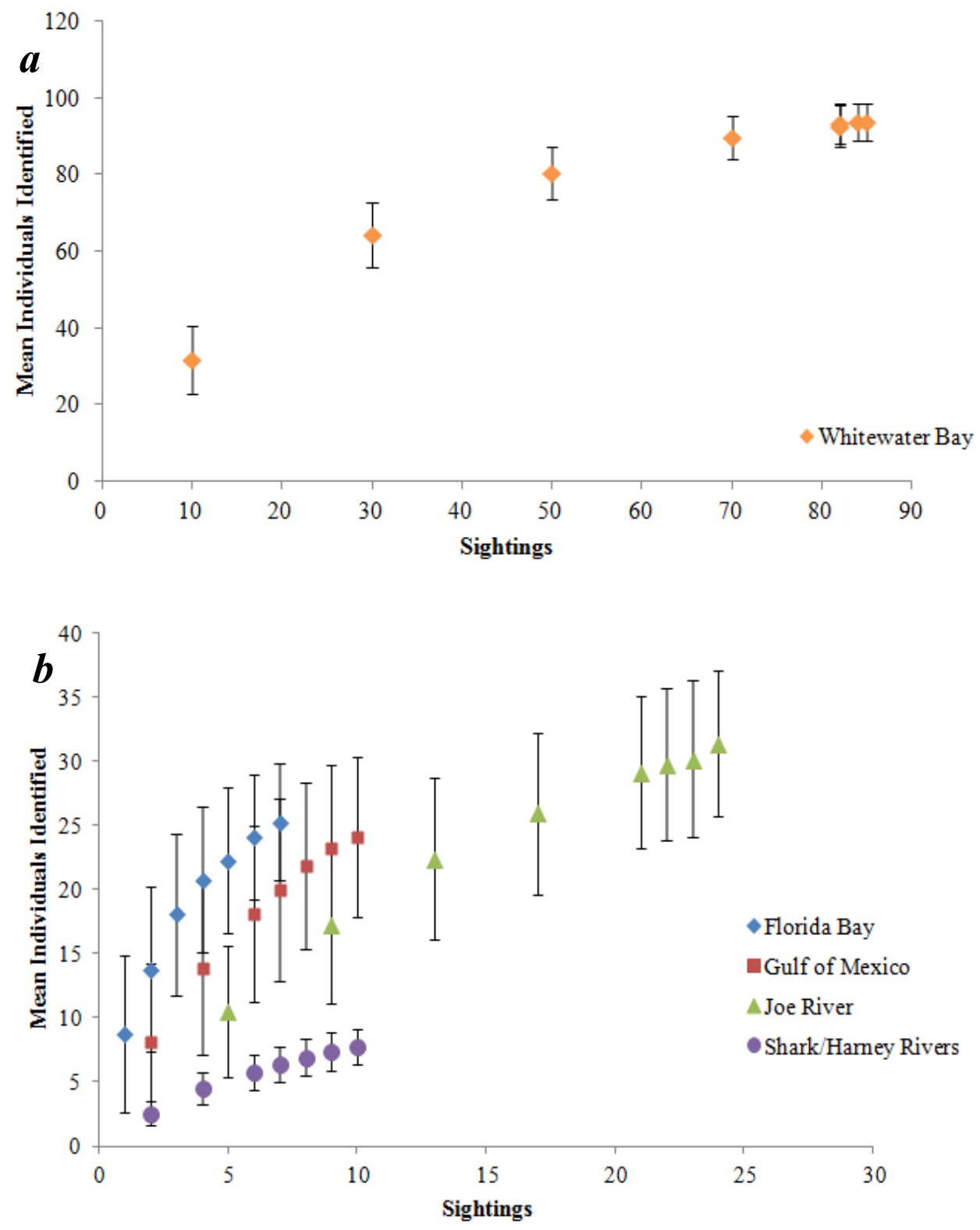

Figure 5 Cumulative individual curves generated by resampling group compositions for 1000 randomly selected groups within Whitewater Bay (a) and the four other regions of the study area (b). Points show means, error bars show standard error. 
Both densities of individuals (Kruskal-Wallis Statistic $=20.18, \mathrm{P}=0.0168)($ Figure 6) and densities of groups (Kruskal-Wallis Statistic $=23.55, \mathrm{P}=0.0044)($ Figure 7$)$ varied significantly in space and in time. Within the rivers, densities of individuals were greater in the dry season (mean $=0.73$ dolphins per $\mathrm{km}^{2} \pm 0.19 \mathrm{SD}$ ) than the wet season (mean=0.14 dolphins per $\left.\mathrm{km}^{2} \pm 0.08 \mathrm{SD}\right)($ Kruskal-Wallis Statistic $=-2.34, \mathrm{P}=0.02)$. Densities of individuals were similar across regions, with the exception of higher abundances in the Joe River in both wet and dry seasons (Kruskal-Wallis Statistic $=18.34, \mathrm{P}=0.001)$ and Florida Bay in the wet season. During the wet season, Florida Bay and Joe River had the highest density of individuals (mean $=1.94$ dolphins $/ \mathrm{km}^{2} \pm 1.29 \mathrm{SD}$ and mean $=1.27 \pm 0.60 \mathrm{SD}$ respectively), and the density in the Gulf of Mexico was significantly less than in Joe River (mean $=0.37 \pm 0.54 \mathrm{SD}$ ). Densities in Whitewater Bay (mean $=0.56 \pm 0.25 \mathrm{SD}$ ) and the Shark and Harney Rivers (mean $=0.14 \pm 0.22 \mathrm{SD}$ ) were not significantly different from those of the Gulf of Mexico but were significantly different from densities in all other regions including each another. Interestingly, the density of foraging animals did not vary across regions (Kruskal-Wallis Statistic $=2.66$, $\mathrm{P}=0.62$ ) and did not change seasonally (Kruskal-Wallis Statistic $=0.21, \mathrm{P}=0.98$ ). Within Whitewater Bay, the probability of encountering groups was higher within $100 \mathrm{~m}$ of mangrove islands than more than $100 \mathrm{~m}$ from islands $(\mathrm{Z}=4.58, \mathrm{P}=0.03)$.

The presence versus absence of calves did not vary among regions (Chi-Square Statistic $=4.70, \mathrm{P}=0.32)$ within the estuary (Chi-Square Statistic $=4.43, \mathrm{P}=0.11)$, or among channels, open water, and mangrove edges within Whitewater Bay (Chi-Square Statistic $=5.35, \mathrm{P}=0.13$ ). Interestingly, during the dry season in the rivers, groups with 
calves were encountered further upstream than those without calves (Kruskal-Wallis Statistic $=2.28, \mathrm{P}=0.02$ ). I was unable to assess whether this pattern occurred in the wet season because only one group with calves was encountered.

I did not detect seasonal variation in group sizes overall or within regions (overall Kruskal-Wallis Statistic $=0.84, \mathrm{P}=0.89$, Florida Bay Kruskal-Wallis Statistic $=1.24$, $\mathrm{P}=0.22$, Gulf Kruskal-Wallis Statistic $=-1.46, \mathrm{P}=0.14$, Joe River Kruskal-Wallis Statistic $=-0.36, \mathrm{P}=0.72$, Shark/Harney River Kruskal-Wallis Statistic $=-1.29, \mathrm{P}=0.20$, Whitewater Bay Kruskal-Wallis Statistic $=-0.29, \mathrm{P}=0.77$ ).

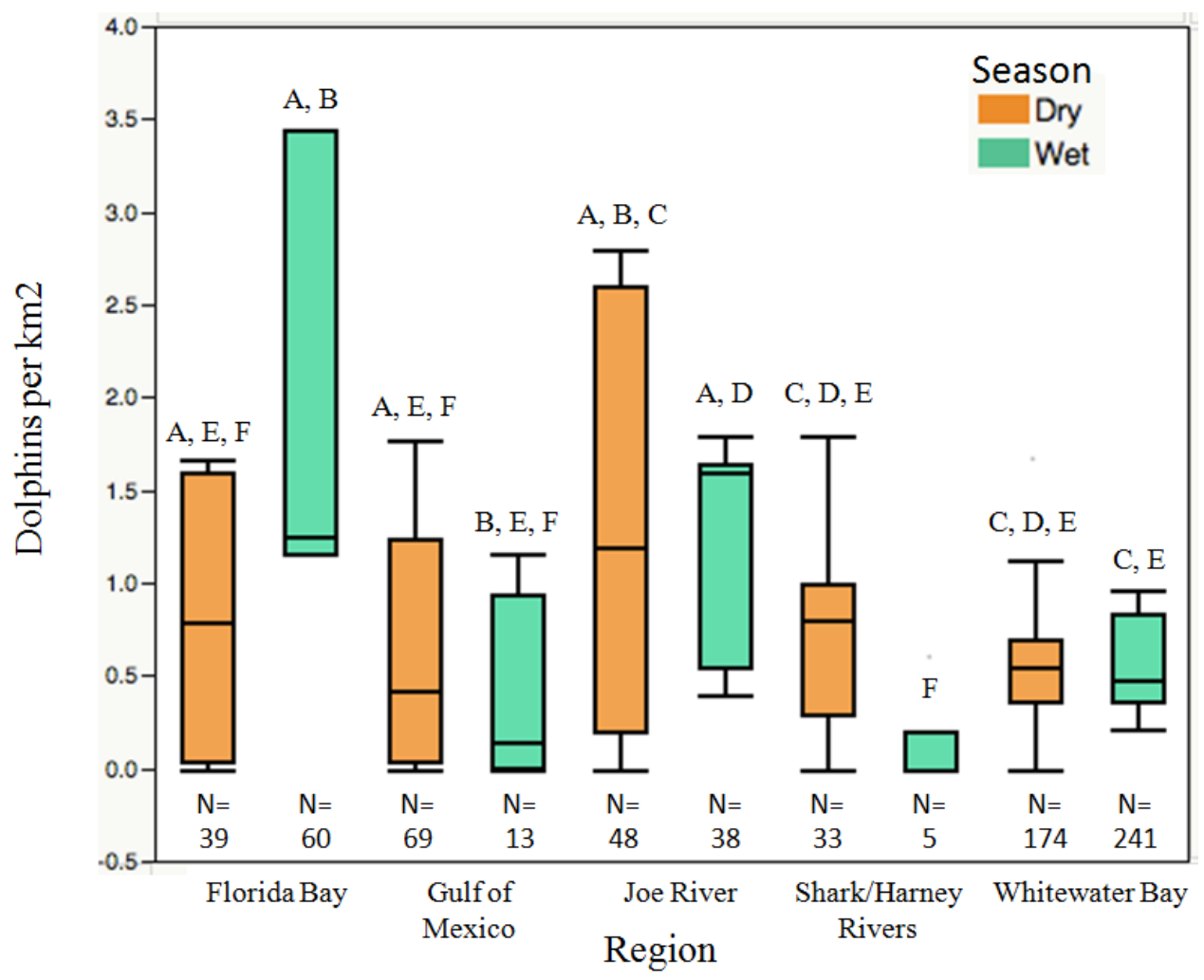

Figure 6 - Spatiotemporal variation in the density of dolphins in the Florida Coastal Everglades. Boxplots show median, quartile, minimum and maximum values; bars with the same letter are not significantly different from one another. . 


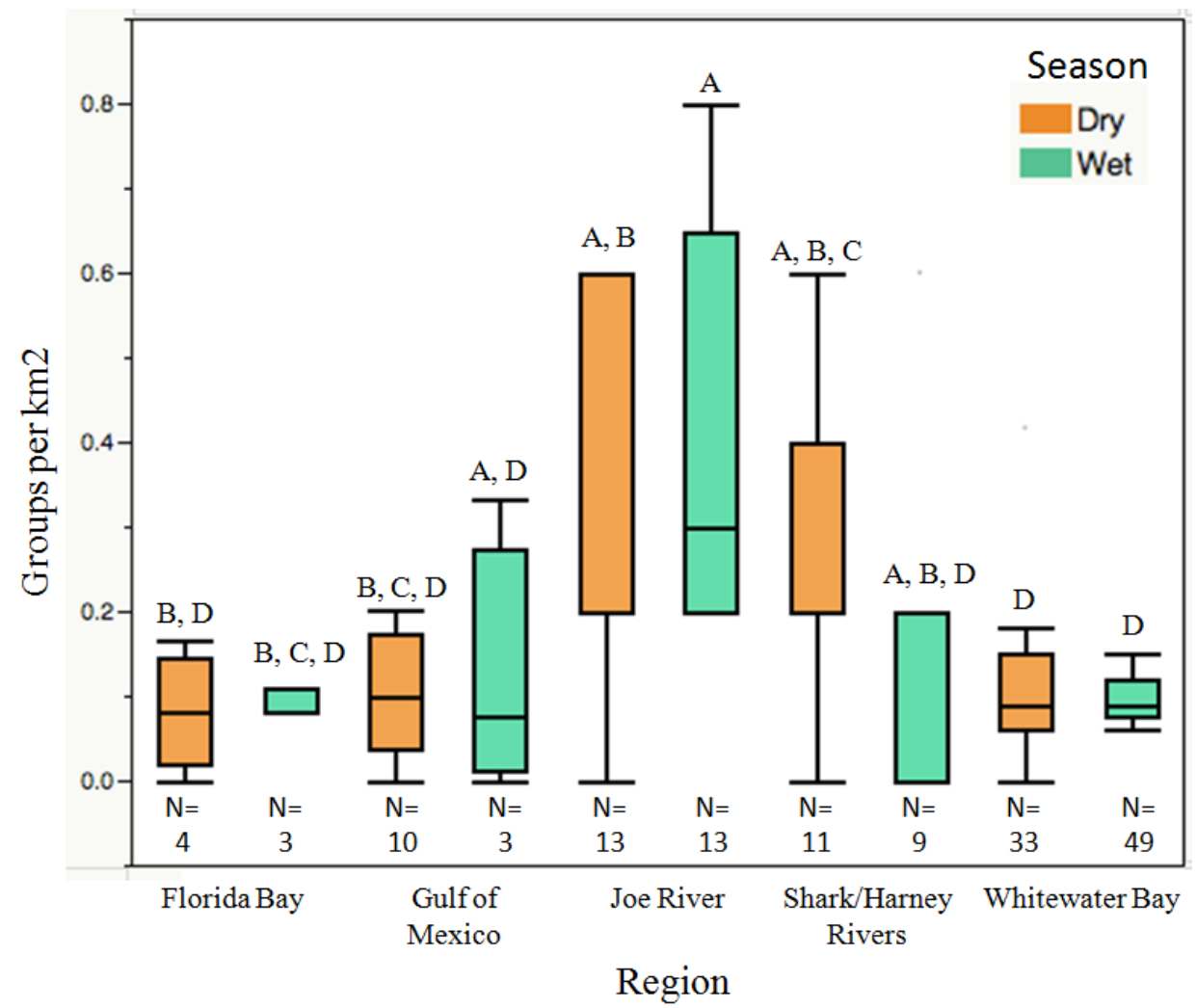

Figure 7 - Spatiotemporal variation in the density of dolphin groups in the Florida Coastal Everglades. Boxplots show median, quartile, minimum and maximum values; bars with the same letter are not significantly different from one another.

Group sizes varied across regions (Kruskal-Wallis Statistic $=25.88, \mathrm{P}<0.0001)$ and among habitats within Whitewater Bay (Kruskal-Wallis Statistic $=17.24, \mathrm{P}=0.0002)$. The smallest groups were found in the rivers (mean=2.10 $\pm 1.65 \mathrm{SD}$ ) and the largest were found in Florida Bay (mean=12.71 $\pm 9.59 \mathrm{SD})$. Mean group sizes were intermediate in the Gulf of Mexico (mean=5.31 $\pm 4.70 \mathrm{SD}$ ), Joe River (mean=3.73 $\pm 2.75 \mathrm{SD}$ ), and Whitewater Bay (mean=5.37 \pm 4.04 SD) (Figure 8,9 ). Interestingly, Whitewater Bay had significantly larger groups than Joe River, despite the high degree of connectivity between the regions. Across habitats within Whitewater Bay, groups were largest in 
open water and smallest around mangrove islands (Figure 10). Finally, when examining groups while excluding calves, groups with juveniles, calves, or neonates were much larger than those without younger age classes within estuarine regions (Figure 13; Kruskal-Wallis Statistic $=15.60, \mathrm{P}=0.004)($ Figure 11).

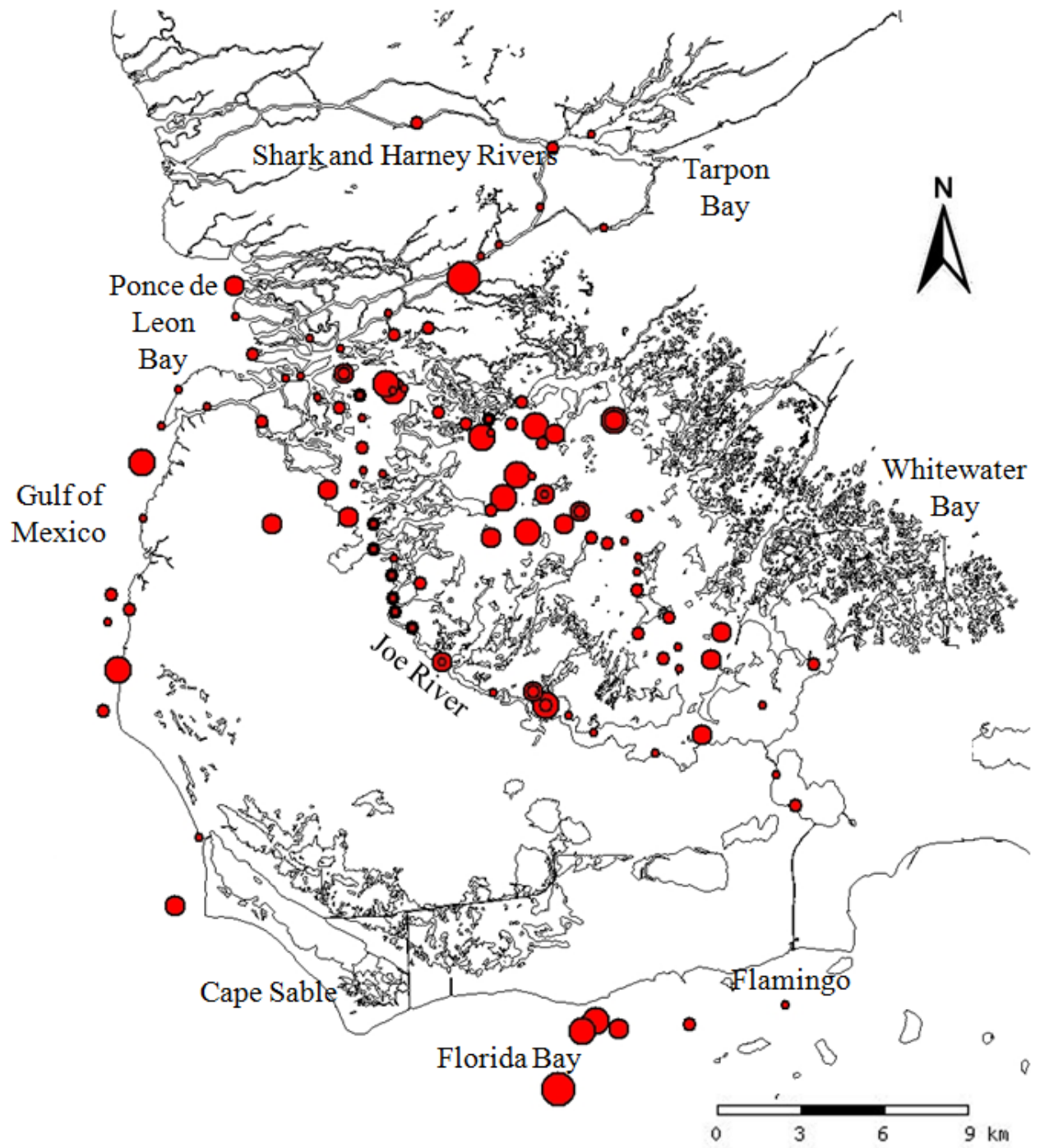

Figure 8- Map showing locations of all groups encountered. Dot size is proportional to group size. 


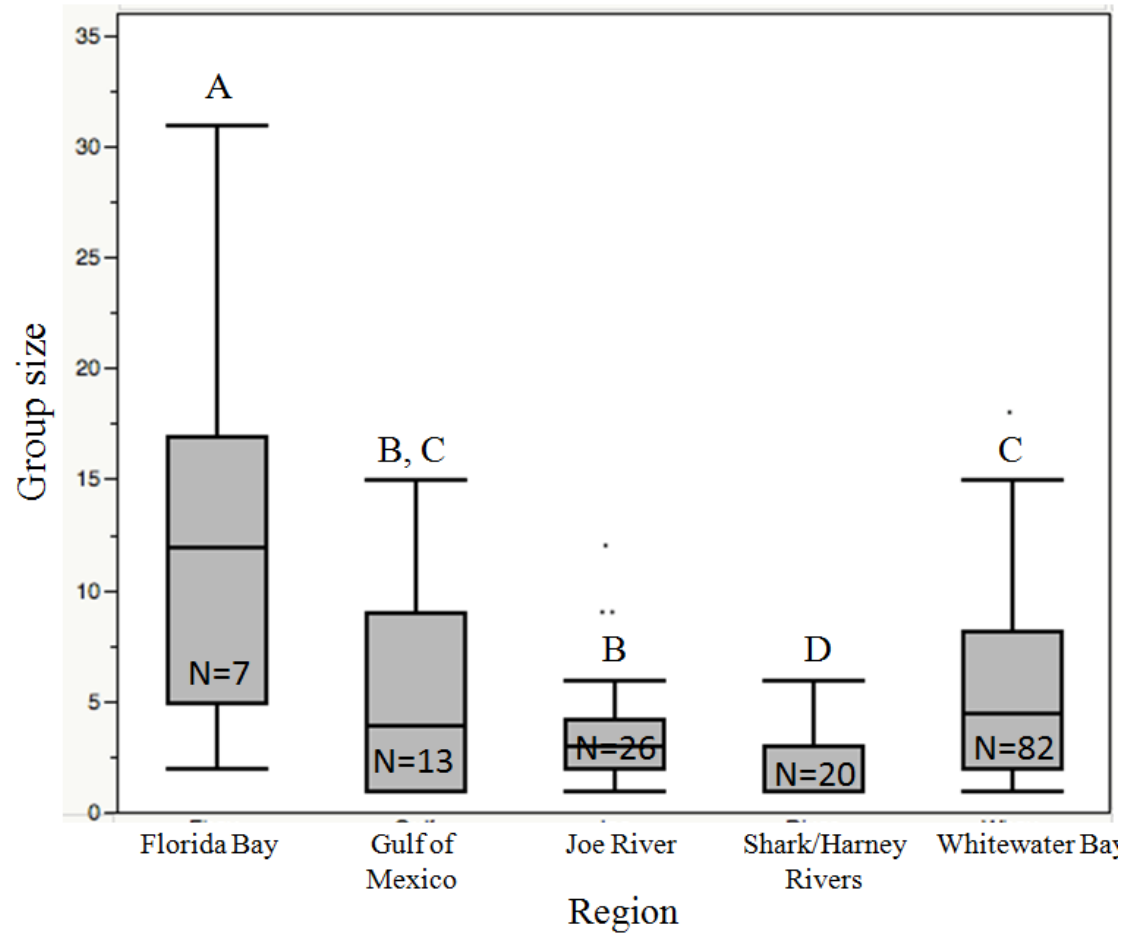

Figure 9 - Regional variation in mean group sizes. There was no seasonal variation in group sizes. Boxplots show median, quartile, minimum and maximum values; bars with the same letter are not significantly different from one another.

Group size varied among behavioral states; traveling groups were significantly smaller (mean $=4.58 \pm 3.34 \mathrm{SD}$ ) than the larger socializing groups (mean=7.92, $\mathrm{SD}=6.01)$; foraging groups were nonsignificantly different from either socializing or traveling groups (Kruskal-Wallis Statistic $=12.72, \mathrm{P}=0.0053$ ). 


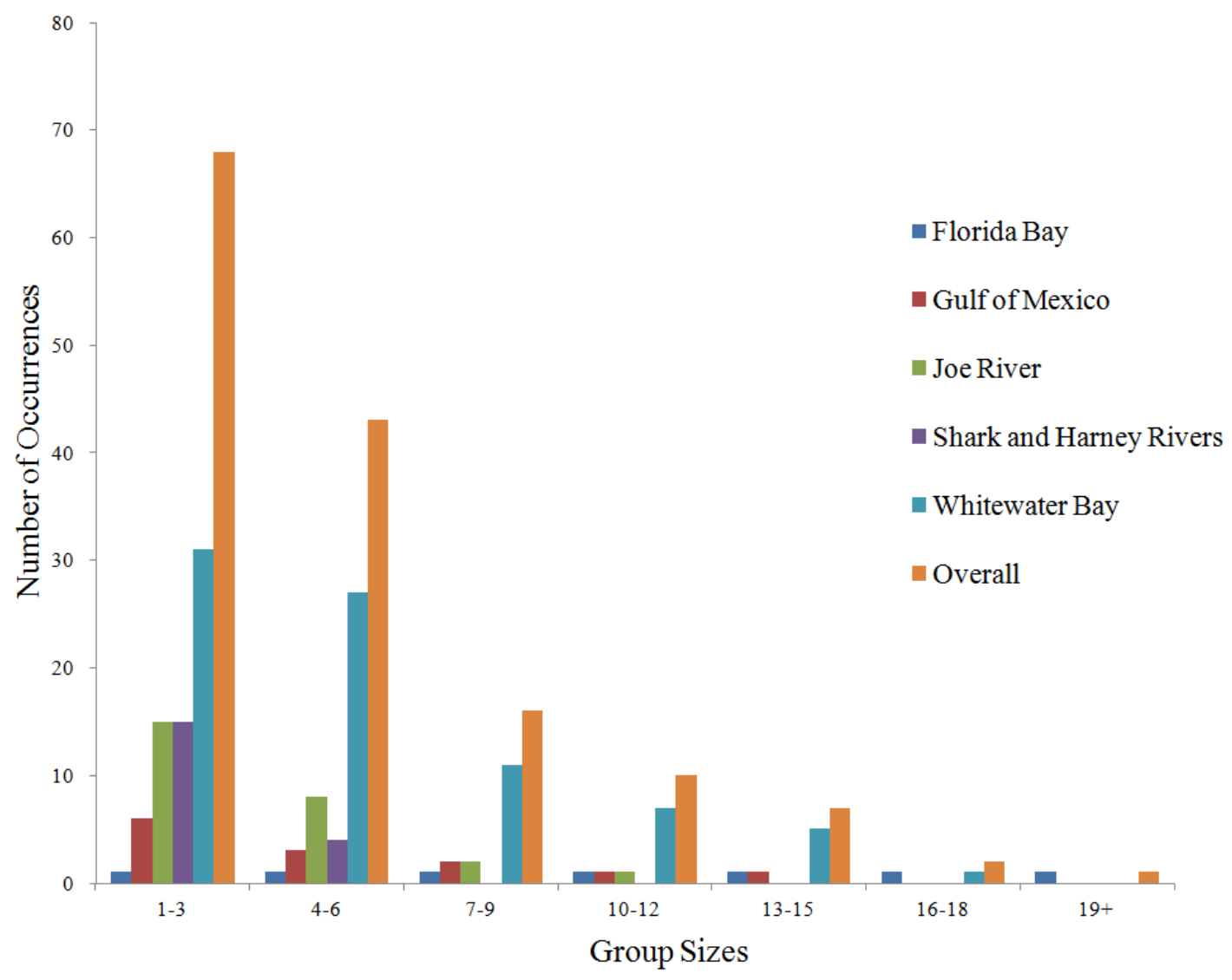

Figure 10 - Distribution of group sizes across the five study zones. Overall, the smallest groups were the most common. Groups in Whitewater Bay most closely resembled overall patterns; group sizes in river habitats were smallest, and group sizes in Florida Bay had the widest variation in size, including the largest groups encountered. 


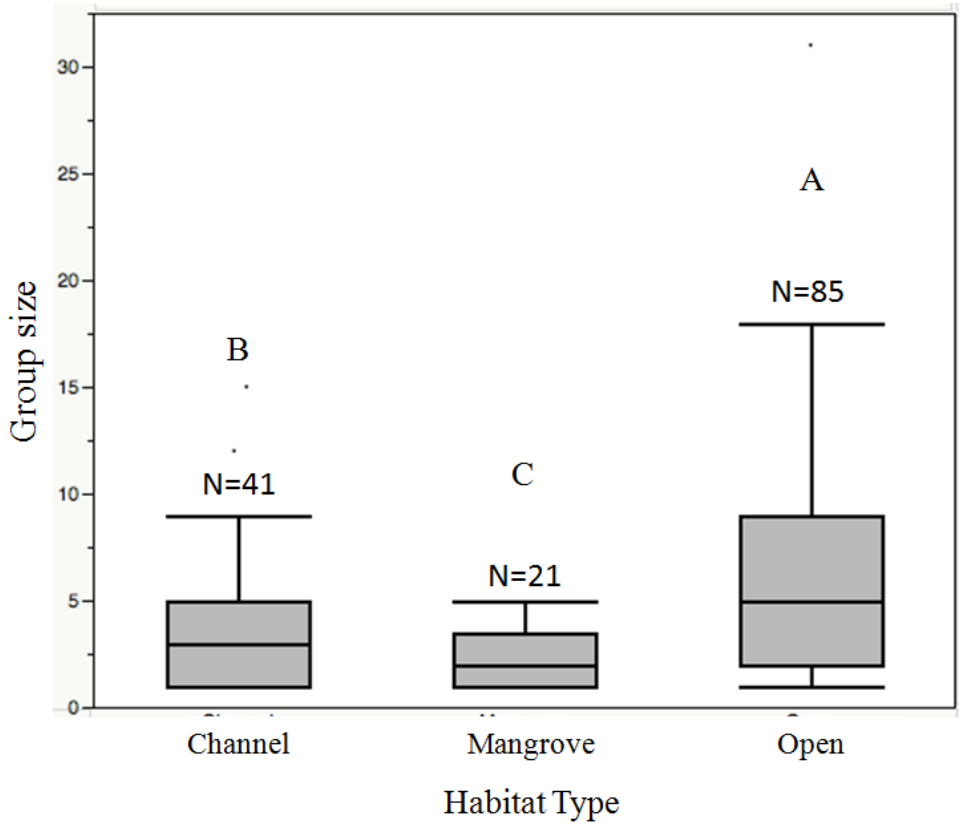

Figure 11 - Variation in group sizes among estuarine habitats. Boxplots show median, quartile, minimum and maximum values; bars with the same letter are not significantly different from one another.

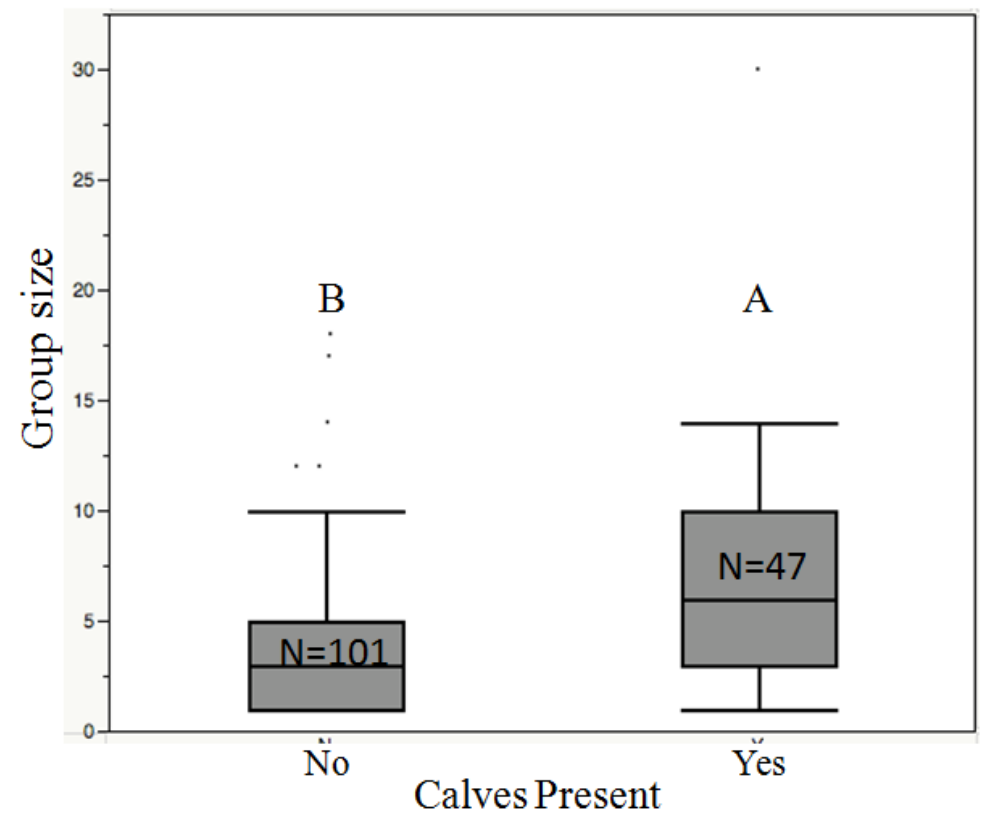


Figure 12 - Influence of group type (presence or absence of calves) on group sizes. Boxplots show median, quartile, minimum and maximum values; bars with the same letter are not significantly different from one another.

\section{DISCUSSION}

Bottlenose dolphins are known to use coastal and estuarine habitats around the world (Wells and Scott 1999). However, few areas exhibit the considerable diversity of habitat types encompassed by the Florida coastal Everglades (FCE). In addition, most studies of estuarine dolphins have occurred in areas with relatively high human densities (e.g., Barros and Wells 1998, Gregory and Rowden 2001, Hastie et al. 2004). Although water flow into the FCE is highly modified and managed by humans, the current study site is typified by low densities of boats and direct human impacts (Ault et al. 2008). I discovered that in spite of considerable seasonal variation in abiotic conditions, bottlenose dolphins in this temporally dynamic environment exhibit relatively stable densities and group sizes within regions, but show considerable variation in their use of regions in the estuary and coastal ocean.

There are three main population types that might be observed in an estuarine system: year-round residents (Wells 1991, Williams et al. 1993, Zolman 2002), temporarily resident seasonal migrants (Scott et al. 1990), or transient animals (Hansen 1990, Bearzi et al. 1997, Defran and Weller 1999). Often, animals from multiple populations are temporarily sympatric (Wells 2003), but there appears to be little genetic interchange despite these periods of intermingling (Hoelzel et al. 1998). Social structure differs 
among these population types. Resident animals tend to be found in small groups that are differentiated by sex and reproductive state and feature a variety of association types (see Wells 1991, Connor et al. 2000) while migratory groups are often large and include all ages and sexes, and associations are more fluid (Defran and Weller 1999).

In the FCE it is clear that there is a year-round residential population, at least in Whitewater Bay and Joe River. Out of the 50 animals sighted four or more times, 45 were sighted in both seasons. The presence of either a seasonal resident or a transient population is possible since 125 animals were observed three times or fewer, with 62 animals sighted only once. Of the individuals sited only once, 36 were from the Gulf of Mexico or Florida Bay. At this time, however, it is not possible to reject the possibility that these rarely sighted individuals are part of a resident population, and simply were not frequently encountered because the survey transects may have only included a small portion of their home ranges. For example, although the transect through Whitewater Bay sampled $33 \mathrm{~km}^{2}$, this is only $c a .16 .5 \%$ of the total area available to dolphins. Additionally, if dolphins in Whitewater Bay exhibited small-scale shifts in habitat use or home ranges similar to those observed in other locations (e.g., Nowacek et al. 2001), they may become unavailable for observation within the transect area.

Residency patterns of dolphins encountered in the Shark and Harney Rivers are similarly difficult to assess; of the 19 animals identified in these rivers, only three were ever sighted elsewhere in the estuary. It is likely that these animals are part of a nearshore population occasionally exploiting the rivers since it is unlikely dolphins were present but 
not sited during river transects due to the narrow width of the transect and calm water conditions. The presence of a nearshore population occasionally entering the estuary could explain the low resighting rates of these animals (only two of the 19 individuals were sighted four times or more). Three animals were observed to switch habitats from estuarine to nearshore Gulf of Mexico; a pattern also observed in Sarasota Bay (Owen et al. 2002). Of the 31 animals identified in Florida Bay, two were later identified in the Gulf of Mexico. No animals seen in any other regions were sighted in Florida Bay. The lack of resightings may be indicative of a separate population or simple isolation by distance. Ponce de Leon Bay is the nearest entrance point to the estuarine Everglades from Florida Bay, which is $32 \mathrm{~km}$ away. Future genetic or isotopic studies may help elucidate population structure in the coastal Everglades region (e.g., Olin et al. 2012).

Dolphin densities varied considerably among regions. Densities of individuals in Florida Bay were consistently high despite having similar group densities to other areas, which is reflective of larger group sizes in Florida Bay. In the Shark and Harney Rivers, the densities of individuals during the dry season were not significantly greater than those found in the rest of the estuarine system, but the densities of groups were greater than those in Whitewater Bay. It was somewhat surprising that densities of both individuals and groups were considerably higher in Joe River than the adjacent Whitewater Bay since they should experience very similar water temperatures and salinities throughout the year. In addition, all of the individuals observed in Joe River were also observed in Whitewater Bay at some time. Because the abundance of large sharks is low in both Whitewater Bay and Joe River (Wiley and Simpfendorfer 2007) and rates of shark-inflicted injuries are 
low, it is unlikely that Joe River provides a refuge from predation. The possibility that dolphins are using Joe River for foraging reasons is not testable at this time because of a lack of data of prey abundance and generally low sample sizes of foraging individuals. However, it is possible that dolphins select Joe River because the greater proportion of mangrove-lined shores facilities foraging. For example, in the Moray Firth, dolphins preferentially foraged over steep seabed gradients that may either provide higher concentrations of prey or increased foraging efficiency (Hastie et al. 2004).

The lack of measurable seasonal variation in dolphin densities (except within rivers) within regions was somewhat surprising given the dynamic nature of the ecosystem. However, the subtropical climate of south Florida, likely facilitates year-round residence and may lead to similar densities within the region across seasons. For example, even at higher latitudes (i.e., south of North Carolina along the Atlantic coast) dolphins tend to be year-round residents (Wells and Scott 1999, Gubbins 2002). The seasonal increase in dolphin abundances in rivers during the dry season is consistent with dolphins taking advantage of foraging opportunities. Indeed, during the dry season there is a pulse of freshwater fish entering the rivers as marsh taxa seek refuge from drying marshes (Rehage and Loftus 2007). In addition, increases in salinity dung the dry season may reduce the physiological costs of accessing these, and resident estuarine, potential prey. Stable isotope (e.g. Matich et al. 2011, Rosenblatt and Heithaus 2011) and fatty acid (Belicka et al. 2012) analysis could provide insights into the contribution of freshwater and estuarine taxa to the diets of dolphins using river habitats. 
The proportion of individuals with scars or wounds from shark bites was quite low (15\%) compared to other locations. For example, boat-based observations of freeswimming animals documented scars of $74.2 \%$ of individuals in Shark (Heithaus 2001) and 36.6\% of individuals in Moreton Bay, Australia (Corkeron et al. 1987). In Sarasota Bay, attack rates are lower. Even though animals were captured and the entire body was assessed, only $31 \%$ of individuals had evidence of having been bitten by sharks (Urian et al. 1998). It is likely that some of the differences in scarring rates between the FCE and these locations is driven by poorer observation conditions in the FCE (e.g. tubid waters, free-swimming animals). When viewed in light of low catch rates of large sharks within the FCE (e.g. Wiley and Simpfendorfer 2007, P. Matich unpublished data), however, scarring data suggest that risk to dolphins is low. Yet, predation rates need not be high in order to elicit strong anti-predator behavior and low scarring rates could be the result of effective anti-predator behavior (e.g. Lima and Dill 1990). Indeed, even though predation pressure is relatively low in Sarasota Bay, dolphins were still found to preferentially use shallower, more complex habitats during the times when bull sharks were most prevalent (Wells et al. 1980).

There appeared to be a general trend of increasing group size with increasing habitat openness, even within estuarine waters. Whitewater Bay had significantly larger groups than Joe River or the Shark and Harney Rivers and groups in channel habitats were smaller than those in open water habitats. Florida Bay had by far the largest group sizes compared to all other regions. In open water regions, prey tend to aggregate in larger patches (Ritz et al. 2011), which may result in larger groups through foraging 
aggregations or facilitate larger groups through the benefits of cooperative foraging (e.g. Creel and Creel 1995, Blundell et al. 2002). The open waters of Florida Bay likely have somewhat higher risk of predation than estuarine habitats (e.g. Torres et al. 2006, Wiley and Simpfendorfer 2007), so it is not possible to distinguish between foraging considerations and anti-predator behavior as drivers of spatial variation in group sizes. In other bottlenose dolphin populations, spatial variation in group sizes has been attributed to age/sex variation in grouping patterns and habitat use (Wells 1993), activity-specific habitat use and group size variation (Miller and Baltz 2010) and multiple dolphin communities that may or may not share overlapping core areas of their home ranges but vary in group sizes (Chilvers et al. 2001, Toth et al. 2012).

Groups with juveniles, calves and neonates were larger in the estuarine regions than in the coastal oceans. In general, it is thought female bottlenose dolphins form nursery bands with loose associations among individuals to reduce the risk of predation to their calves (Wells et al. 1987). In Sarasota Bay, females with calves are most sociable and occupy the largest groups - usually within estuaries - when their calves are younger (Scott et al. 1990, Barco et al. 1999). Interestingly, in my study, the probability of sighting a group with calves did not vary across regions. Based on patterns observed in Florida Bay, higher probabilities of sighting calves would have been expected in estuarine waters. Thus, it is possible that there are two separate populations or communities within the study area, specifically an estuarine community and a coastal ocean community. It is possible, however, that use of the river is influenced by predators of dolphins. Groups containing calves were found further upstream than those without 
calves. Juvenile bull sharks (Carcharinhus leucas) use upstream areas of the rivers to reduce the risk of predation from large sharks (Heithaus et al. 2009). Sharks large enough to be predators of juvenile sharks and young dolphins are encountered only at the mouth of the Shark River and coastal oceans (Wiley and Simpfendorfer 2007; Matich unpublished data), so moving upstream could reduce predation risk.

The results of my study suggest that the impacts of the planned Everglades restoration project will vary across the population. The animals using the Shark and Harney Rivers appear to be the most likely to be impacted. The upcoming CERP restoration will increase the amount of fresh water flowing through the system, potentially reducing the magnitude of dry-down and resulting prey pulses. In addition, salinities will be reduced throughout the system, potentially increasing metabolic costs to dolphins using some areas. Long-term studies will allow more detailed investigations of the biotic and abiotic factors impacting dolphin densities and habitat use and provide important insights into likely responses to restoration. In addition, incorporating stable isotopic or fatty acid analysis would provide insights into the foraging ecology of dolphins and be an important first step in elucidating their ecological roles in the coastal Everglades. 
Alexander RD. 1974. The evolution of social behavior. Annual Review of Ecology and Systematics 5: 325-383

Allen MC, Read AJ, Gaudet J, Sayigh LS. (2001) Fine-scale habitat selection of foraging bottlenose dolphins Tursiops truncatus near Clearwater, Florida. Marine Ecology Progress Series 222: 253-264

Ansmann IC, Parra GJ, Chilvers BL, Lanyon JM. 2012. Dolphins restructure social system after reduction of commercial fisheries. Animal Behaviour 84: 575-581

Ault JS, Smith SG, McClellan DB, Zurcher N, McCrea A, Vaughan NR, Bohnsack JA. 2008. Aerial survey of boater use in Everglades National Park marine waters - Florida Bay and Ten Thousand Islands. NOAA Technical Memorandum NMFS-SEFSC-581

Ballance LT. (1992) Habitat use patterns and ranges of the bottlenose dolphin in the Gulf of California, Mexico. Marine Mammal Science 8: 262-274

Barco SG, Swingle WM, McLellan WA, Harris RN, Pabst DA. 1999. Local abundance and distribution of bottlenose dolphins (Tursiops truncatus) in the nearshore waters of Virginia Beach, Virginia. Marine Mammal Science 15: 394-408

Barros NB, Wells RS. 1998. Prey and feeding patterns of resident bottlenose dolphins (Tursiopstruncatus) in Sarasota Bay, Florida. Journal of Mammalogy 79: 1045-1059

Barros NB, Ostrom PH, Stricker CA, Wells RS. 2010. Stable isotopes differentiate bottlenose dolphins off west-central Florida. Marine Mammal Science 26: 324-336

Bassos MK. 1993. A behavioral assessment of the reintroduction of two bottlenose dolphins. Master's thesis, University of California, Santa Cruz.

Bearzi G, Notoarbatolo-di-Sciara G, Politi E. 1997. Social ecology of bottlenose dolphins in Kvarneri (northern Adriatic Sea). Marine Mammal Science 13: 650-668

Belicka LL, Matich P, Jaffe R, Heithaus MR. 2012. Fatty acids and stable isotopes as indicators of early-life feeding and potential maternal resource dependency in the bull shark Carcharhinus leucas. Marine Ecology Progress Series 455: 245-256

Bertram BCR. 1978. Living in groups: Predators and prey. In "Behavioural Ecology: An Evolutionary Approach" (CJ Krebs and NB Davies, eds), pp. 64-96. Blackwell Scientific Publications, London.

Bizzarro JJ, Robinson HJ, Rinewalt CS, Ebert DA. 2007. Comparative feeding ecology 
of four sympatric skate species off central California, USA. Environmental Biology of Fishes 80: 197-220

Blundell GM, Ben-David M, Bowyer RT. 2002. Sociality in river otters: Cooperative foraging or reproductive strategies. Behavioral Ecology 13: 134-141

Bowen WD (1997) Role of marine mammals in aquatic ecosystems. Marine Ecology Progress Series 158: 267-274

Boyer JN, Fourqurean JW, Jones RD. 1997. Spatial characterization of water quality in Florida Bay and Whitewater Bay by multivariate analyses: Zones of similar influence. Estuaries 20: 743-758

Caldwell DK. 1955. Evidence of home range of an Atlantic bottlenose dolphin. Journal of Mammalogy 36: 304-305.

Campbell GS, Bilgre BA, Defran RH. 2002. Bottlenose dolphins (Tursiops truncatus) in Turneffe Atoll, Belize: occurrence, site fidelity, group size, and abundance. Aquatic Mammals 28: 170-180

CERP: The Plan in Depth. The Comprehensive Everglades Restoration Plan. CERP, n.d. Web. 5 Jul 2011. <http://www.evergladesplan.org/>.

Chick JH, Ruetz CR, Texler JC. 2004. Spatial scale and abundance patterns of large fish communities in freshwater marshes of the Florida Everglades. Wetlands 24: 652-664

Childers DL. 2006. A synthesis of long-term research by the Florida Coastal Everglades LTER Program. Hydrobiologia: 569: 531-544

Childers DL, Boyer JN, Davis SE, Madden CJ, Rudnick DT, Sklar FH. 2006. Relating precipitation and water management to nutrient contents in the oligotrophic "upside down" estuaries of the Florida Everglades. Limnology and Oceanography 51: 602-616

Chilvers BL, Corkeron PJ. 2001. Trawling and bottlenose dolphins' social structure. Proceedings of the Royal Society of London B 268: 1901-1905

Connor RC. 2001. Individual foraging specializations in marine mammals: Culture and ecology. Behavioral and Brain Sciences 24: 329-330.

Connor RC, Smolker RA, Richards AF. 1992. Two levels of alliance formation among male bottlenose dolphins (Tursiops sp.) Proceedings of the National Academy of Sciences of the United States of America 89: 987-990

Connor RC, Heithaus MR, Barre LM. 1999. Superalliance of bottlenose dolphins. Nature 397: $571-572$ 
Connor RC, Wells RS, Mann J, Read AJ. 2000. The bottlenose dolphin: Social relationships in a fission-fusion society. In "Cetacean Societies: Field Studies of Dolphins and Whales" (J Mann, RC Connor, P Tyack and H Whitehead, eds), pp. 91-126. University of Chicago Press, Chicago

Connor RC, Heithaus MR, Barre LM. 2001. Complex social structure, alliance stability and mating access in a bottlenose dolphin 'super-alliance.' Proceedings of the Royal Society of London B 268: 263-267

Corkeron PJ, Morris RJ, Bryden MM. 1987. Interactions between bottlenose dolphins and sharks in Moreton Bay, Queensland. Aquatic Mammals 13: 109-113

Coulson RA, Herbert JD, Coulson TD. 1989. Biochemistry and physiology of alligator metabolism in vivo. American Zoologist 29: 921-934

Creel S, Creel NM. 1995. Communal hunting and pack size in African wild dogs Lycaon pictus. Animal Behavior 50: 1325-1339

Curry BD, Smith J. 1997. Phylogeographic structure of the bottlenose dolphin (Tursiops truncatus): Stock identification and implications for management. 227-247. In A.E. Divons, S.J. Chivers and W.F. Perrin, eds, Molecular Genetics of Marine Mammals. Lawrence, DS: Special Publication no. 3, Society for Marine Mammalogy.

Davis SM, Childers DL, Lorenz JJ, Wanless HR, Hopkins TE. 2005. A conceptual model of ecological interactions in the mangrove estuaries of the Florida Everglades. Wetlands 25: $832-842$

Defran DH, Weller DW. 1999. Occurrence, distribution, site fidelity and school size of bottlenose dolphins (Tursiops truncatus) off San Diego, California. Marine Mammal Science 15: 366-380

Elliser CR, Herzing DL. 2011. Replacement dolphins? Social restructuring of a resident pod of Atlantic bottlenose dolphins, Tursiops truncatus, after two major hurricanes. Marine Mammal Science 27: 39-59

Fernandez R., Garcia-Tiscar S, Santos MB, Lopez A, Matrinez-Cedeira JA, Newton J, Pierce GJ. 2011. Stable isotope analysis in two sympatric populations of bottlenose dolphins Tursiops truncatus: evidence of resource partitioning? Marine Biology 158: 1043-1055

Fury C, Harrison P. (2008) Abundance, site fidelity and range patterns of Indo-Pacific bottlenose dolphins (Tursiops aduncus) in two Australian subtropical estuaries. Marine and Freshwater Research 59: 1015-1027 
Gaiser E. 2009. Periphyton as an indicator of restoration in the Florida Everglades. Ecological Indicators 9: S37-S45

Gannon DP, Barros NB, Nowacek DP, Read AJ, Waples DM, Wells RS. 2005. Prey detection by bottlenose dolphins, Tursiops truncatus: an experimental test of the passive listening hypothesis. Animal Behaviour 69: 709-720

Gowans S, Wursig B, Karczmarski L. 2008. The social structure and strategies of delphinids: Predictions based on an ecological framework. Advances in Marine Biology 53: $195-294$

Gregory PR, Rowden AA. 2001. Behaviour patterns of bottlenose dolphins (Tursiops truncatus) relative to tidal state, time-of-day, and boat traffic in Cardigan Bay, West Wales. Aquatic Mammals 27: 105-113

Gubbins C. 2002. Use of home ranges by resident bottlenose dolphins (Tursiops truncatus) in a South Carolina estuary. Journal of Mammalogy 83: 178-187

Hansen LH. 1990. Coastal California bottlenose dolphins. In "The Bottlenose Dolphin" (S Leatherwood and RR Reeves, eds), pp. 403-420. Academic Press, New York

Hastie GD, Wilson B, Wilson LJ, Parsons KM, Thompson PM. (2004) Functional mechanisms underlying cetacean distribution patterns: hotspots for bottlenose dolphins are linked to foraging. Marine Biology 144: 397-794.

Heithaus MR. 2001. Shark attacks on bottlenose dolphins (Tursiops aduncus) in Shark Bay, Western Australia: Attack rate, bite scar frequencies, and attack seasonality. Marine Mammal Science 17: 526-539

Heithaus MR, Dill LM. 2002 Food availability and tiger shark predation risk influence bottlenose dolphin habitat use. Ecology 83: 480-491

Heithaus MR, Dill LM. 2006. Does tiger shark predation risk influence foraging habitat use by bottlenose dolphins at multiple spatial scales? Oikos 114: 257-264

Heithaus MR, Delius BK, Wirsing AJ, Dunphy-Daly MM. 2009. Physical factors influencing the distribution of a top predator in a subtropical oligotrophic estuary. Limnology and Oceanography 54: 472-482

Hoelzel AR, Potter CW, Best PB. 1998. Genetic differentiation between parapatric 'nearshore' and 'offshore' populations of bottlenose dolphins. Proceedings of the Royal Society of London B 265:1177-1183

Irvine AB, Scott MD, Wells RS, Kaufmann JH. 1981. Movements and activities of the 
Atlantic bottlenose dolphin, Tursiops truncatus, near Sarasota, Florida. Fishery Bulletin 79: 671-688.

Irwin LJ, Wursig B. 2004. A small resident community of bottlenose dolphins, Tursiops truncatus, near Sarasota, Florida. Fishery Bulletin 79: 671-688.

Krutzen M, Mann J, Heithaus MR, Connor RC, Bejder L, Sherwin WB. 2005 Cultural transmission of tool use in bottlenose dolphins. Proceedings of the National Academy of Science 102: 8939-8943.

Lewis JS, Schroeder WW. 2003. Mud plume feeding, a unique foraging behavior of the bottlenose dolphin in the Florida Keys. Gulf of Mexico Science 21: $92-97$

Lorenz JJ, Serafy JE. 2006. Subtropical wetland fish assemblages and changing salinity regimes: Implications for everglades restoration. Hydrobiologia 569: 401-422

Mann JM, Connor RC, Barre LM, Heithaus MR. 2000. Female reproductive success in bottlenose dolphins (Tursiops sp.) : life history, habitat, provisioning, and group size effects. Behavioral Ecology 11: 210-219

Mann JM, Sargeant B, Watson-Capps JJ, Gibson QA, Heithaus MR, Connor RC, Patterson E, Brooks R. 2008. Why do dolphins carry sponges? PloS ONE 3: 1-7

Matich PA, Heithaus MR, Layman CA. 2011. Contrasting patterns of individual specialization and trophic coupling in two marine apex predators. Journal of Animal Ecology 80: 294-305

Mazzotti FJ, Best GR, Brandt LA, Cherkiss MS, Jeffery BM, Rice KG. 2009. Alligators and crocodiles as indicators for restoration of Everglades ecosystems. Ecological Indicators 9: S137-S149

McCabe EJB, Gannon DP, Barros NB, Wells RS. 2010. Prey selection by resident common bottlenose dolphins (Tursiops truncatus) in Sarasota Bay, Florida. Marine Biology 157: 931-942

McHugh KA, Allen JB, Barleycorn AA, Wells RS. 2011. Natal philopatry, ranging behavior, and habitat selection of juvenile bottlenose dolphins in Sarasota Bay, Florida. Journal of Mammalogy 92: 1298-1313

McHugh KA, Allen JB, Barleycorn AA, Wells RS. 2011. Severe Karenia brevis red tides influence juvenile bottlenose dolphin (Tursiops truncatus) behavior in Sarasota Bay, Florida. Marine Mammal Science 27: 622-643

Miller CE, Baltz DM. 2010. Environmental characterization of seasonal trends and 
foraging habitat of bottlenose dolphins (Tursiops truncatus) in northern Gulf of Mexico bays. Fishery Bulletin 108: 79-86

Moore JC. 1953. Distribution of marine mammals to Florida waters. American Midland Naturalist 49: 117-158

NOAA. 2010. US Atlantic and Gulf of Mexico Marine Mammal Stock Assessments 2010: Bottlenose Dolphin (Tursiops truncatus): Florida Bay Stock. NOAA Technical Memorandum NMFS-NE219: 479-483

Nowacek SM, Wells RS, Solow R. 2001. Short term effects of boat traffic on bottlenose dolphins, Tursiops truncatus, in Sarasota Bay, Florida. Marine Mammal Science 17: 673688

Olin JA, Fair PA, Recks MA, Zolman E, Adams J, Fisk AT. 2012. Unique seasonal forage bases within a local population of bottlenose dolphin (Tursiops truncatus). Marine Mammal Science 28: 28-40.

Owen ECG, Wells RS, Hofmann S. 2002. Ranging and association patterns of paired and unpaired adult male Atlantic bottlenose dolphins Tursiops truncatus, in Sarasota, Florida, provide no evidence for alternative male strategies. Canadian Journal of Zoology 80: 2072-2089

Patterson EM, Mann J. (2011)The Ecological conditions that favor tool use and innovation in wild bottlenose dolphins (Tursiops sp.) PLoS ONE 7: e22243

Perry W. 2004. Elements of South Florida's Comprehensive Everglades Restoration Plan. Ecotoxicology 13: 185-193

Rehage JS, Trexler JC. 2006. Assessing the net effect of anthropogenic disturbance on aquatic communities in wetlands: community structure relative to distance from canals. Hydrobiologia 569: 359-373

Rehage JS, Loftus WF. 2007. Seasonal fish community variation in headwater mangrove creeks in the southwestern Everglades: and examination of their role as dry-down refuges. Bulletin of Marine Science 80: 625-645

Ritz DA, Hobday AJ, Montogomery JC, Ward AJW. 2011. Chapter Four - Social aggregation in the pelagic zone with special reference to fish and invertebrates. Advances in Marine Biology 60: 161-227

Rosenblatt AE, Heithaus MR. 2011. Does variation in movement tactics and trophic interactions among American alligators create habitat linkages? Journal of Animal Ecology 80: 786-798 
Sargeant BL, Wirsing AJ, Heithaus MR, Mann J. 2007. Can environmental heterogeneity explain individual foraging variation in wild bottlenose dolphins (Tursiops sp.)?

Behavioral Ecology and Sociobiology 61: 679-688

Schmid TH, Murru FL. 1994. Bioenergetics of the bull shark, Carcharhinus leucas, maintained in captivity. Zoo Biology 13: 177-185

Schomer NS, Drew RD. 1982. An ecological characterization of the lower Everglades, Florida Bay, and the Florida Keys. U.S. Fish and Wildlife Service, Office of Biological Services, Washington, D.C.

Scott MD, Wells RS, Irvine AB. 1990. A long-term study of bottlenose dolphins on the west coast of Florida. In "The Bottlenose Dolphin" (S Leatherwood and RR Reeves, eds), pp. 143-154. Academic Press, New York

Shane SH. 1990. Behavior and ecology of the bottlenose dolphin at Sanibel Island, Florida. In "The Bottlenose Dolphin" (S Leatherwood and RR Reeves, eds), pp. 245-266. Academic Press, New York

Shane SH. 2004. Residence patterns, group characteristics, and association patterns of bottlenose dolphins near Sanibel Island, Florida. Gulf of Mexico Science 22: 1-12

Shane SH, Wells RS, Wursig B. 1986. Ecology, behavior, and social organization of the bottlenose dolphin: a review. Marine Mammal Science 2: 34-63

Silber GK, Fertl D. 1995. Intentional beaching by bottlenose dolphins (Tursiops truncatus) in the Colorado River Delta, Mexico. Aquatic Mammals 21: 183-186

Smolker RA, Richards AF, Connor RC, Pepper JW. 1992. Sex differences in patterns of association among Indian Ocean bottlenosed dolphins. Behaviour 123: 38-69.

Stocktin KA, Weir CR, Pierce GJ. 2006. Examining the importance of Aberdeenshire (UK) coastal waters for North Sea bottlenose dolphins (Tursiops truncatus). Journal of the Marine Biological Association of the United Kingdom 86: 201-207

Torres LG, Read AJ. 2009. Where to catch a fish? The influence of foraging tactics on the ecology of bottlenose dolphins (Tursiops truncatus) in Florida Bay, Florida. Marine Mammal Science 25: 797-815

Torres LG, Urban D. 2005. Using spatial analysis to assess bottlenose dolphins as an indicator of healthy fish habitat. Pages 423-435 in Estuarine Indicators.

Torres LG, Read AJ, Halpin P. 2008. Fine-scale habitat modeling of a top marine predator: Do prey data improve predictive capacity? Ecological Applications 18: 17021717 
Toth JL, Hohn AA, Able KW, Gorgone AM. 2011. Patterns of seasonal occurrence, distribution, and site fidelity of coastal bottlenose dolphins (Tursiops truncatus) in southern New Jersey, U.S.A. Marine Mammal Science 27: 94-110

Toth JL, Hohn AA, Able KW, Gorgone AM. 2012. Defining bottlenose dolphin (Tursiops truncatus) stocks based on environmental, physical, and behavioral characteristics. Marine Mammal Science 28: 461-478

Trexler JC, Loftus WF, Perry S. 2005. Disturbance frequency and community structure in a twenty-five year intervention study. Oecologia 145: 140-152

Trexler JC, Goss CW. 2009. Aquatic fauna as indicators for Everglades restoration: Applying dynamic targets in assessments. Ecological Indicators 9: S108-S119

Turner AM, Trexler JC, Jordan CF, Slack SJ, Geddes P, Chick JH, Loftus WF. 1999. Targeting ecosystem features for conservation: Standing crops in the Florida Everglades. Conservation Biology 13: 898-911

Urian KW, Wells RS, Scott MD, Irvine AB, Read AJ, Hohn AA. 1998. When the shark bites: An analysis of shark bite scars on wild bottlenose dolphins (Tursiops truncatus) from Sarasota, Florida. The World Marine Mammal Conference, Monaco 20-24 January, 1998, Abstracts: 139

Weir JS, Duprey NMT, Wursig B. 2008. Dusky dolphin (Lagenorhynchus obscures) subgroup distribution: are shallow waters a refuge for nursery groups? Canadian Journal of Zoology 86: 1225-1234

Wells RS. 1991. The role of long-term study in understanding the social structure of a bottlenose dolphin community. 199-225. In K. Pryor and K.S. Norris, eds., Dolphin Societies: Discoveries and Puzzles. Berkeley: University of California Press

Wells RS. 1993. The marine mammals of Sarasota Bay. 9.1-9.23. In Sarasota Bay: 1992 Framework for Action. Sarasota FL: Sarasota Bay National Estuary Program.

Wells RS. 2003. Dolphin social complexity: Lessons from long term study and life history. In "Animal Social Complexity: Intelligence, Culture and Individualized Societies." (FBM. de Waal and P L Tyack, eds), pp. 32-56. Harvard University Press, Cambridge, Massachusetts.

Wells RS, Scott MD. 1999. Bottlenose dolphin Tursiops truncatus (Montagu 1821). In "Handbook of Marine Mammals." (SH Ridway and R Harrison, eds), pp. 137-182. Academic Press, San Diego

Wells RS, Irvine AB, Scott MD. 1980. The social ecology of inshore odontocetes. In 
"Cetacean Behavior: Mechanisms and Functions" (LM Herman, ed.) pp. 263-317. John Wiley \& Sons, Toronto.

Wells RS, Scott MD, Irvine AB. 1987. The social structure of free-ranging bottlenose dolphins. In "Current Mammalogy." (H H Genoways, ed.), pp. 247-305. Plenum Press, New York

Wells RS, Rhinehart HL, Cunningham P, Whaley J, Baran M, Koberna C, Costa DP. 1999. Long distance offshore movements of bottlenose dolphins. Marine Mammal Science 15: 1098-1114

Wiley TR, Simpfendorder CA. 2007. The ecology of elasmobranchs occurring in the Everglades National Park, Florida: implications for conservation and management. Bulletinof Marine Science 80: 171-189

Williams JA, Dawson SM, Slooten E. 1993. The abundance and distribution of bottlenose dolphins (Tursiops truncatus) in Doubtful Sound, New Zealand. Canadian Journal of Zoology 71: 2080-2088

Williams TM, Estes JA, Doak DF, Springer AM. 2004. Killer appetites: Assessing the role of predators in ecological communities. Ecology 85: 3373-3384

Williams AJ, Trexler JC. 2006. A preliminary analysis of the correlation of food-web characteristics with hydrology and nutrient gradients in the southern Everglades. Hydrobiologia 569: 493-504

Wilson DS. 1975. A theory of group selection. Proceedings of the National Academy of Sciences of the United States of America, Washington. 72: 143-146

Wilson B, Thompson PM, Hammond PS. 1997. Habitat use by bottlenose dolphins: seasonal distribution and stratified movement patterns in the Moray Firth, Scotland. Journal of Applied Ecology 34: 1365-1374

Wursig B, Wursig M. 1977. The Photographic Determination of Group Size, Composition, and Stability of Coastal Porpoises (Tursiops truncatus). Science 198: 755756

Yeates LC, Houser DS. 2008. Thermal tolerance in bottlenose dolphins (Tursiops truncatus) Journal of Experimental Biology 211: 3249-3257

Young RF, Phillips HD. 2002. Primary production required to support bottlenose dolphins in a salt marsh estuarine creek system. Marine Mammal Science 18: 358-373

Zolman ES. 2003. Residence patterns of bottlenose dolphins (Tursiops truncatus) in the 
Stono River Estuary, Charleston County, South Carolina, U.S.A. Marine Mammal Science 18: 879-892 